\title{
Reactive Oxygen Species in Acute Lymphoblastic Leukaemia: Reducing Radicals to Refine Responses
}

\author{
Abdul Mannan 1,2 (D), Zacary P. Germon ${ }^{1,2} \mathbb{D}$, Janis Chamberlain ${ }^{1,2,3}$, Jonathan R. Sillar ${ }^{1,2,4}$, Brett Nixon ${ }^{2,5} \mathbb{D}$ and \\ Matthew D. Dun $1,2, *$ (i)
}

1 Cancer Signalling Research Group, School of Biomedical Sciences and Pharmacy, College of Health, Medicine and Wellbeing, University of Newcastle, Callaghan, NSW 2308, Australia; Abdul.Mannan@newcastle.edu.au (A.M.); Zacary.Germon@uon.edu.au (Z.P.G.); Janis.Chamberlain@health.nsw.gov.au (J.C.); Jonathan.Sillar@uon.edu.au (J.R.S.)

2 Hunter Medical Research Institute, New Lambton Heights, NSW 2305, Australia; Brett.Nixon@newcastle.edu.au

3 John Hunter Children's Hospital, New Lambton Heights, NSW 2308, Australia

4 Calvary Mater Hospital, Waratah, NSW 2298, Australia

5 Reproductive Science Group, College of Engineering, Science and Environment, University of Newcastle, Callaghan, NSW 2308, Australia

* Correspondence: matt.dun@newcastle.edu.au; Tel.: +61-2-4921-5693

Citation: Mannan, A.; Germon, Z.P.; Chamberlain, J.; Sillar, J.R.; Nixon, B.; Dun, M.D. Reactive Oxygen Species in Acute Lymphoblastic Leukaemia: Reducing Radicals to Refine Responses. Antioxidants 2021, 10, 1616. https://doi.org/10.3390/ antiox10101616

Academic Editor: Alex Tonks

Received: 8 September 2021

Accepted: 9 October 2021

Published: 14 October 2021

Publisher's Note: MDPI stays neutral with regard to jurisdictional claims in published maps and institutional affiliations.

Copyright: (c) 2021 by the authors. Licensee MDPI, Basel, Switzerland. This article is an open access article distributed under the terms and conditions of the Creative Commons Attribution (CC BY) license (https:// creativecommons.org/licenses/by/ $4.0 /)$.

\begin{abstract}
Acute lymphoblastic leukaemia (ALL) is the most common cancer diagnosed in children and adolescents. Approximately $70 \%$ of patients survive $>5$-years following diagnosis, however, for those that fail upfront therapies, survival is poor. Reactive oxygen species (ROS) are elevated in a range of cancers and are emerging as significant contributors to the leukaemogenesis of ALL. ROS modulate the function of signalling proteins through oxidation of cysteine residues, as well as promote genomic instability by damaging DNA, to promote chemotherapy resistance. Current therapeutic approaches exploit the pro-oxidant intracellular environment of malignant $\mathrm{B}$ and $\mathrm{T}$ lymphoblasts to cause irreversible DNA damage and cell death, however these strategies impact normal haematopoiesis and lead to long lasting side-effects. Therapies suppressing ROS production, especially those targeting ROS producing enzymes such as the NADPH oxidases (NOXs), are emerging alternatives to treat cancers and may be exploited to improve the ALL treatment. Here, we discuss the roles that ROS play in normal haematopoiesis and in ALL. We explore the molecular mechanisms underpinning overproduction of ROS in ALL, and their roles in disease progression and drug resistance. Finally, we examine strategies to target ROS production, with a specific focus on the NOX enzymes, to improve the treatment of ALL.
\end{abstract}

Keywords: acute lymphoblastic leukaemia; reactive oxygen species; oxidative stress; NADPH oxidases; antioxidants; redox homeostasis; second messenger signalling; oxidative DNA damage; resistance; oncogenic signalling; cysteine oxidation; kinase; phosphatase

\section{Introduction}

Acute lymphoblastic leukaemia (ALL) is a heterogeneous malignancy of immature $\mathrm{B}$ or $\mathrm{T}$ lymphoblasts, which rapidly proliferate in the bone marrow, blood, and some extra-medullary sites such as the spleen and lymph nodes [1]. ALL is the most common form of childhood cancer [2], and although only 20\% of ALL diagnoses are diagnosed in adults, four out of five deaths from ALL are in this age group [3]. The overall survival (OS) of children diagnosed with ALL has dramatically improved over the last 40 years. Indeed, the development of multidrug treatment regimens including vincristine $[1,4]$, corticosteroids [5], and asparaginase [6], with most regimens adding an anthracycline [7] (usually doxorubicin or daunorubicin) has reduced treatment resistance, and led to remission rates of greater than $80 \%$ [4]. The backbone of ALL treatment is similar in adults; however, 
they have worse outcomes due to both higher risk disease features at diagnosis and more toxicities associated with therapies $[1,4,8]$. However, in both populations the early failure of upfront therapies has devastating consequences, with a median 5 -year OS of $21 \%$ for children [8] and $2 \%$ for adults who relapse within their first year of diagnosis [9]. These concerning data highlight the need to continually develop treatments for ALL patients at diagnosis and at disease progression.

A handful of risk factors are associated with ALL including, prenatal exposure to X-rays, postnatal exposure to high doses of radiation and previous treatments with chemotherapy [10], with a genetic predisposition seen in a subset of ALL cases. These include rare genetic and familial cancer syndromes, DNA polymorphisms in non-coding genes and numerous germline variants in coding genes [11]. Chromosomal abnormalities are also common in ALL and include gain or loss of chromosomal content (aneuploidy) and chromosomal rearrangements. Typical chromosomal translocations include, $\mathrm{t}(9 ; 22)$ [BCR/ABL1], t(12;21) [ETV6/RUNX1], t(1;19) [TCF3/PBX1], and Mixed-lineage leukaemia (MLL)-rearrangements [1]. Overall consequences of chromosomal abnormalities are the loss of tumour suppressor genes or production of chimeric proteins that dysregulate many cellular processes particularly those that underpin cellular development, differentiation, multiplications, and cell cycle regulation [4]. Recurring somatic and occasionally germline mutations in transcription factors (IKZF1, STAT5) [12,13], tumour suppressors TP53 (including germline variants), CDKN2A [14,15], and signalling pathways genes such as NOTCH1 [16], PI3K/Akt (FLT3, PTEN, PTPN11) [17-20], JAK/STAT (CLRF2, IL7R, JAK1, $J A K 3)[21,22]$ and $\operatorname{Ras}(B C R / A B L, N R A S, K R A S)[23,24]$ drive malignant transformation of immature lymphocytes and perturb the function of the body's immune system. Recurring mutations in signalling genes are strongly associated with pathways that underpin the increased production of reactive oxygen species (ROS); oxidative radicals that induce DNA damage leading to genomic instability and promote leukaemogenesis [25]. However, the roles of ROS in redox signalling and genome instability in ALL remains enigmatic and infantine. In this review, we summarise the known roles that ROS fulfil in the dysfunction of ALL blasts and discuss therapeutic interventions with particular attention given to strategies that reduce ROS production used in combination with established standard-of-care chemotherapies and targeted therapies.

\section{Reactive Oxygen Species}

ROS are a heterogenous group of small molecules, ions and radicals derived from oxygen molecules that share the property of being highly reactive due to the presence of unpaired electrons. Some of the common examples of ROS include superoxide anion $\left(\mathrm{O}_{2}{ }^{-}\right)$, nitric oxide $\left(\mathrm{NO}^{-}\right)$, hydroxyl radical $\left(\mathrm{HO}^{-}\right)$, hydrogen peroxide $\left(\mathrm{H}_{2} \mathrm{O}_{2}\right)$, ozone $\left(\mathrm{O}_{3}\right)$, and lipid peroxides [26]. The main free-radical, superoxide anion, and the non-free radical, hydrogen peroxide, are the two most important ROS, with each playing multiple roles in the regulation of cellular signalling and biological processes [25]. The role of ROS in normal and cancer-associated signalling have been studied extensively over the last couple of decades [27], revealing multiple mechanisms underpinning their cancer associated effects, including the modulation of cell signalling [28], oxidative DNA damage [29], promoting genomic instability [30], and lipid peroxidation [31]. It follows that cancer stemness and self-renewal [32,33], cancer progression, resistance to standard-or-care treatment [34] and relapse are all associated with the levels of ROS production in cancer [29,35]. Other than cancer, ROS also play deleterious roles in other diseases such as neurodegeneration [36], fertility [37], ageing [38], diabetes [39], and hypertension [39].

\section{Sources of Reactive Oxygen Species}

The nicotinamide adenine dinucleotide phosphate (NADPH) oxidases (NOXs) and mitochondrial respiratory chain complexes are the two main sources of intracellular ROS production [26]. The NOX family of enzymes are transmembrane proteins embedded in the plasma membrane, predominantly in immune cells and produce ROS as part of the 
phagosome [40]. Neutrophils, monocytes, and macrophages lyse invading pathogens using ROS produced by a NOX2 initiated respiratory burst [41-43]. Multiple stimuli, including bacterial lipopolysaccharide (LPS), tumour necrosis factor-alpha (TNF), and interleukin (IL-1), can activate NOXs [44]. However, the expression of the NOX family of enzymes is not limited to immune cells; they are also found in various tissues including the intestine [45], vascular smooth muscles [46], lung epithelium [47], kidneys [48], spleen, uterus [49], endothelial cells [50] testis, lymph nodes [51], and the brain to aid in angiogenesis [52] and are pivotal in regulating a multitude of normal cellular processes. NOX-driven ROS production is implicit in redox regulated post-translational modifications (PTMs) as is frequently seen in cysteine containing enzymes. Such oxidatively driven PTMs result in the modulation of enzyme structure and folding with downstream consequences for their cellular signalling activity and hence ability to influence gene expression and cellular differentiation $[44,53]$.

The catalytic subunits of human NOX enzyme complexes consist of p22 phox $(C Y B A)$, NOX1 (NOX1), NOX2, commonly referred to as gp91 phox (CYBB), NOX3 (NOX3), NOX4 (NOX4), NOX5 (NOX5), Dual oxidase 1 (DUOX1), and DUOX2 (DUOX2). NOX2 was the first NOX isoform characterised and it catalyses the production of superoxide on plasma membranes by transferring one electron from the intracellular NADPH to extracellular or luminal oxygen. The catalytic subunits of NADPH oxidases (NOX1-5, DUOX1-2) also require interaction with regulatory subunits to modulate their activity. NOX2, for example, has six regulatory subunits: two membrane-bound p2 $2^{\text {phox }}$ and Ras-related protein 1 (Rap1), and four cytoplasmic $440^{\text {phox }}$ (NCF4), p47 phox (NCF1), p67 phox (NCF2) and the Ras-related C3 botulinum toxin substrate (RAC1 and $R A C 2)$ proteins. The activation of NOX1-4 requires heterodimerisation with p2 $^{\text {phox }}$, with NOX5 and DUOX1-2 activated independent of $\mathrm{p} 22^{\text {phox }}$ but requires calcium. While all other NOX isoforms catalyse the production of superoxides, NOX4 and DUOX1-2 produce hydrogen peroxides through the peroxidaselike domain [44]. Therefore, the differential expression of these isoforms can determine the dominant ROS produced in a specific tissue and/or organelle.

Mitochondria are the other major source of ROS production. Indeed, superoxide was first discovered from the mitochondria, wherein it is produced by the electron transport chain complexes located within the inner mitochondrial membrane [54,55]. Specifically, during oxidative phosphorylation electron leakage from the respiratory chain enzyme complexes I and III release superoxide anion [56]. Superoxide anions are subsequently converted into the more stable hydroxyl radical $\left(\mathrm{HO}^{-}\right)$and hydrogen peroxide $\left(\mathrm{H}_{2} \mathrm{O}_{2}\right)$ [57]. Endoplasmic reticulum and peroxisomes can also contribute to cellular $\mathrm{H}_{2} \mathrm{O}_{2}$. The relative stability of $\mathrm{H}_{2} \mathrm{O}_{2}$ ensures a longer half-life than superoxide, and the chemical has the added properties of being able to radially diffuse across cell membranes via aquaporins (peroxiporins), act as a secondary messenger in cellular signalling [58], and react with cysteines leading to temporary or permanent redox PTM of signalling proteins [59]. Despite increased stability, $\mathrm{H}_{2} \mathrm{O}_{2}$ still can damage lipids and proteins especially in the presence of iron, via a phenomenon called the Fenton reaction [59].

Mammalian cells have evolved complex antioxidant systems that can counter the toxic effects of elevated $\mathrm{H}_{2} \mathrm{O}_{2}$ and hence cellular oxidative stress (Figure 1) (reviewed in [60]). These antioxidant systems are mainly divided into enzymatic and non-enzymatic processes that are crucial in maintaining a balance between oxidative stress and essential redox signalling, often referred to as redox homeostasis. Enzymatic antioxidants include superoxide dismutase (SOD), catalase (CAT), and glutathione peroxidase (GPx), thioredoxin (TRX), peroxiredoxin (PRX) and glutathione transferase (GST) [61]. The spontaneous or enzymatic dismutation of superoxide by SOD produces $\mathrm{H}_{2} \mathrm{O}_{2}$, oxygen $\left(\mathrm{O}_{2}\right)$ and water $\left(\mathrm{H}_{2} \mathrm{O}\right)$; however, $\mathrm{H}_{2} \mathrm{O}_{2}$ can be also be reduced to hydroxyl radicals (HO) [62]. There are three different isoforms of SOD; manganese (Mn)-SOD (SOD2) which is mainly located in the mitochondria, SOD1 in the cytoplasm and SOD3 in the extracellular space [58]. Oxidative stresses such as ionisation radiation induces the expression of SOD2 to balance increased oxidative stress observed within the mitochondrial space [63]. Importantly, knock-out 
of SOD2 is neonatally lethal in mice, a phenotype that results from excessive oxidative DNA damage and biochemical aberrations within the mitochondria, thus highlighting the essential role of SOD2 in mitochondrial function and redox homeostasis [64].

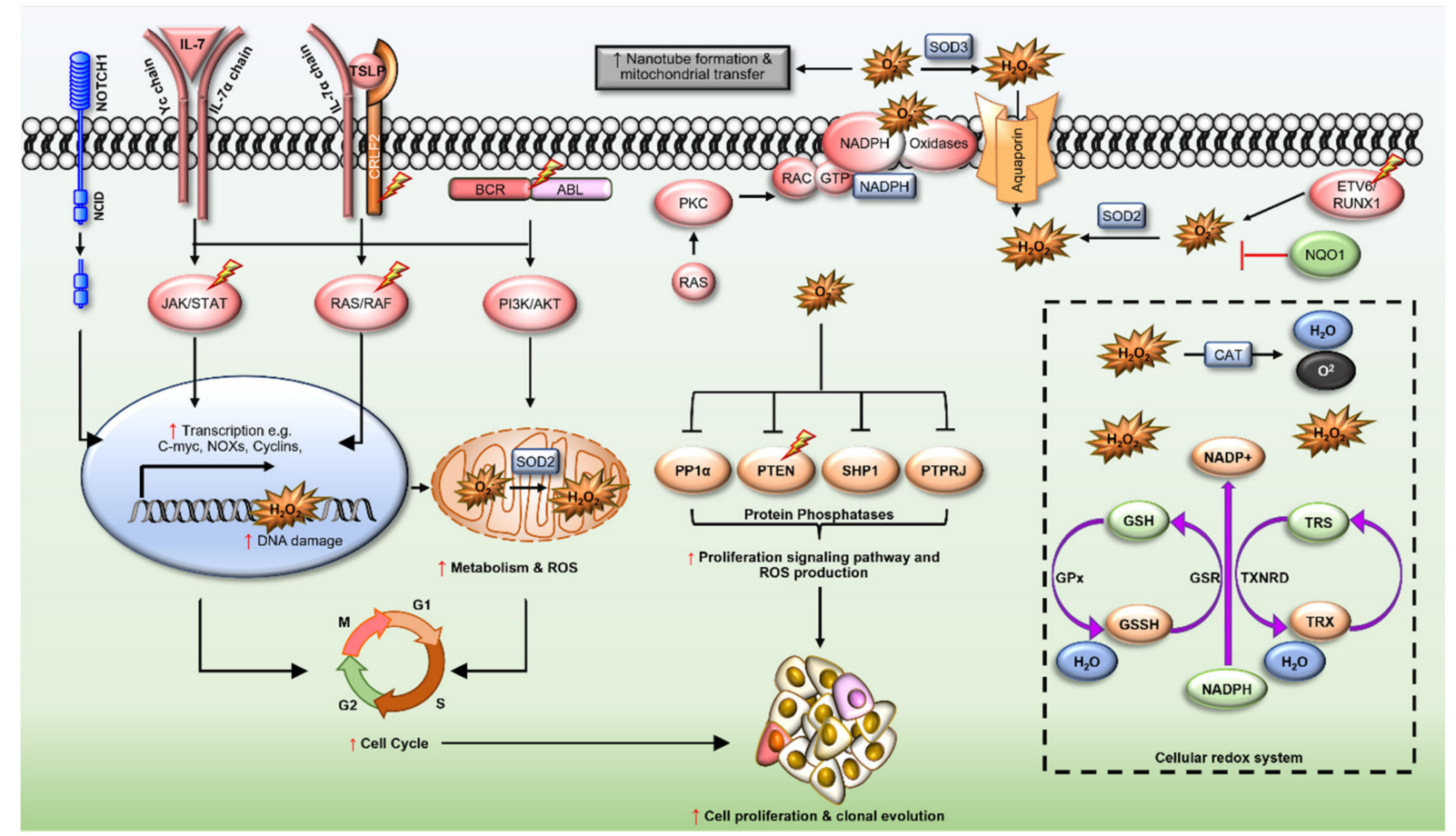

Figure 1. Signalling pathways linked to reactive oxygen species production in acute lymphoblastic leukaemia. Recurring somatic mutations to CRLF2, JAK, NQO1, NOTCH1 and RAS, chromosomal translocations such as BCR/ABL and ETV6/RUNX1 as well as overexpression of CRLF2 and IL7 receptor drive excessive production of intracellular reactive oxygen species (ROS) production (superoxide- $\mathrm{O}_{2}{ }^{-}$and hydrogen peroxide- $\mathrm{H}_{2} \mathrm{O}_{2}$ ) in acute lymphoblastic leukaemia (ALL). High-level ROS production drives redox signalling through oxidative posttranslational modifications that increase the activity of kinases and inactivate protein tyrosine phosphatases, and cause lipid peroxidation and genomic instability leading to leukaemia progression and chemotherapy resistance. Cellular redox systems (shown in the hashed rectangle) regulate ROS homeostasis by converting $\mathrm{H}_{2} \mathrm{O}_{2}$ to water and suppress ROS induced apoptosis. Red shapes = proteins with increased activity or expression; dark green = proteins with decrease activity or expression; orange = oxidised proteins; light green $=$ reduced proteins.

Cysteinyl residues within certain proteins such as in peroxiredoxins and selenocysteinyl residues in GPx (myeloperoxidase- $M P O$, eosinophil peroxidase- $E P X$, lactoperoxidase $-L P O$ ) react with the $\mathrm{H}_{2} \mathrm{O}_{2}$ and lipid hydroperoxides, and as such, form the basis of the mammalian antioxidant system [65]. GPx reduces $\mathrm{H}_{2} \mathrm{O}_{2}$ and lipid peroxides to their respective alcohols using low molecular weight thiols such as GSH; one of the most abundant non-protein thiols found ubiquitously in mammalian cells. GPx catalyses the oxidation of reduced GSH and converts it into a disulphide-oxidised form (GSSG), thereby also converting $\mathrm{H}_{2} \mathrm{O}_{2}$ into $\mathrm{H}_{2} \mathrm{O}$ and $\mathrm{O}_{2}$. GPx, TRX and PRX are other thiol-containing enzymes involved in the clearance of $\mathrm{H}_{2} \mathrm{O}_{2}$ in cells. These antioxidant systems require NADPH to maintain the pool of reduced substrates for the reduction of $\mathrm{H}_{2} \mathrm{O}_{2}$. For example, GSSG reductase uses NADPH to convert GSSG into its reduced form, GSH [61]. The first-rate limiting enzyme of the pentose phosphate pathway, glucose-6-phosphate dehydrogenase, generates intracellular NADPH by reducing $\mathrm{NADP}^{+}$. Therefore, glucose-6-phosphate dehydrogenase is essential to maintain GSH and is regarded as a regulatory antioxidant enzyme. The GST family of enzymes mainly inactivate secondary metabolites, including epoxides and hydroperoxides. Vitamin $C$, vitamin E, glutathione, carotenoids ( $\beta$-Carotene) and flavonoids are among the more common of the non-enzymatic antioxidants. The antioxidant activity of these compounds rests with non-enzymatic mechanisms such as the 
donation of electrons (vitamin $\mathrm{E}$ ( $\alpha$-tocopherol), GSH), scavenging of $\mathrm{O}_{2}$ radicals (vitamin A), chelation of metal ions and trapping of free radicals [61].

As summarised, ROS are produced continuously within eukaryotic cells owing to constant metabolic and biochemical responses. Under normal physiological conditions, cells maintain a dynamic equilibrium between the production and clearance of ROS utilising the plethora of antioxidant systems described above. However, multiple external and internal factors, including ionising radiation, xenobiotic chemicals including anticancer drugs, and pathogens, can disrupt this equilibrium resulting in higher production and/or reduced clearance of ROS with a net shift towards increased oxidative stress levels. Owing to the role of ROS in activating multiple oncogenic signalling pathways and in promoting oxidative DNA damage, overproduction of ROS can result in the initiation and progression of multiple diseases, including ALL.

\section{The Essential Role of ROS in the Maintenance of Haemopoietic Stem Cells (HSCs), and Innate and Adaptive Immunity}

Haemopoietic stem cells (HSCs) are specialised cells residing within the complex environment of bone marrow endosteal region, called niches. HSCs can self-renew to maintain their pool and differentiate into each of the different blood cell types [25]. Bone marrow niches have a relatively low oxygen tension, thereby creating a hypoxic environment favouring the quiescent state of HSCs. Most HSCs are in a state of quiescence and produce low levels of adenosine triphosphates (ATPs) via anaerobic glycolysis to fulfil their energy demands [66]. Self-renewal and quiescence of HSCs is maintained in part by hypoxia-inducible factor 1 alpha (HIF1A) [67], the master regulator of hypoxiainducible gene expression in response to low oxygen. Knockdown of HIF1A in HSCs reduces quiescence and self-renewal ability and increases ROS production $[68,69]$.

In addition to HIF signalling, ataxia-telangiectasia mutation (ATM), forkhead box class $\mathrm{O}$ transcription factor (FoxO), Akt, and mTOR signalling pathways are also crucial in the regulation of redox homeostasis and HSCs quiescence (reviewed in [60]). FoxOs are transcriptional factors that act downstream to PTEN/PI3K/Akt pathway, considered essential for the self-renewal capacity of HSCs. Loss of FoxO3a in HSCs abrogates their longterm self-renewal ability, accompanied by increased phosphorylation of p38 MAPK, and elevation of ROS production [70]. Similarly, conditional deletion of FoxO1/3/4 in adult HSCs reduces their long-term repopulating activity with a commensurate increase in cell cycling and apoptosis mediated through elevated levels of ROS. The ability of the antioxidant $\mathrm{N}$-acetyl-L-cysteine (NAC) to reverse this defective phenotype of FoxO-deficient HSCs [71] highlights the role of ROS in HSC pathophysiology.

Upstream of FoxO, the PI3K/Akt pathway is one of the most upregulated pathways in cancer, including ALL [21,72]. The activation of PI3K/Akt promotes cell cycle progression and mitochondrial oxidative phosphorylation which is associated with increased ROS production in cancer [73]. Akt directly activates NOX to potentiate ROS production through the phosphorylation of $\mathrm{p} 47^{\text {phox }}$ [74]. Conditional deletion of PTEN, the negative regulator of PI3K/Akt signalling, enhances cell cycle progression, proliferation, differentiation, and reduces self-renewal of HSCs [75]. Similarly, chronic activation of Akt in HSCs increases proliferation and loss of HSCs self-renewal [76]. However, Akt1/2-deficient HSCs produce very little ROS and harbour very poor long-term transplantation efficacy due to persistent quiescence at the G0 phase of the cell cycle. Pharmacological increase of ROS rescues differentiation defects of $A k t 1 / 2$-deficient HSCs [77].

The mammalian target of rapamycin (mTOR) is another downstream regulator of PI3K/Akt pathways and promotes mitochondrial oxidative phosphorylation and ROS production. The conditional deletion of tuberous sclerosis complex (Tsc1), the negative regulator of mTOR, drives cell cycle activity in murine HSCs through increased mitochondrial biogenesis and elevated ROS production, thereby impairing self-renewal. Rapamycin, an inhibitor of mTOR, rescued the effects of Tsc1 deletion in mouse HSCs [78].

Ataxia-telangiectasia mutated (ATM, a member of the PIKK (PI3K-like protein kinase) family, is a key stress response protein heavily involved in DNA damage repair and through 
yet an unknow mechanism regulates ROS. Genetic deletion of $\left(\mathrm{Atm}^{-{ }^{-}}\right)$increased ROS levels and reduced self-renewal ability of HSCs, rescued by treatment with the antioxidant NAC [79]. Redox PTMs in ATM increase NADPH production via the pentose phosphate shunt, with NADPH required for the reduction of oxidized glutathione and thioredoxin [80] (Figure 1), a possible mechanism of elevated ROS in ATM-deficient HSCs.

Janus kinases (JAKs) and Signal transducer and activator of transcription (STATs) proteins are important in maintenance of HSC self-renewal and stemness. Jak2 knock-out $\left(J a k 2^{-/-}\right.$) leads to foetal death through perturbations in erythropoiesis, while conditional loss of Jak1 impairs self-renewal disrupting haematopoiesis [81]. Jak2 ${ }^{-/-}$increased ROS levels and p38 MAPK phosphorylation with the concomitant loss of HSCs self-renewal and bone marrow failure in mice [82]. Similarly, STAT3/STAT5, critical haematopoietic transcription factors are activated by phosphorylation by JAK, are implicated in the self-renewal capacity of HSCs [81]. Given JAK phosphorylates and activates STAT, which is linked to ROS production in leukaemia [30,83] (discussed in Section 6), it is interesting that Jak2 ${ }^{-/-}$ knockout increased ROS levels in HSCs. It is quite possible that in HSCs, STAT activity promotes expression of antioxidant proteins, while aberrant DNA methylation in ALL leads to hypermethylation of antioxidant and tumour suppressor genes [84]. Importantly, the pathways involved in the self-renewal HSCs regulate the levels of ROS, emphasising the importance of redox homeostasis in haematopoiesis. In addition, multiple other proteins and pathways, such as tumour suppressors p53 (TP53) and retinoblastoma protein (RB), glycogen synthase kinase-3 (GSK-3), cyclin dependent kinases (CDK), and BCL2 all play an important role in self-renewal, maintaining quiescence, proliferation, differentiation and survival of HSCs mainly through the modulation of mitochondrial ROS [85]. ROS, therefore, plays an essential role in the quiescence, self-renewal, and long-term survival of HSCs, and hence, elevated, and sustained ROS exposure is likely to contribute to cell cycle progression, DNA damage and the initiation and progression of ALL.

ROS also plays an important role in both innate and adaptive immune responses [86]. Chronic granulomatous disease (CGD), a primary immunodeficiency condition in which individuals are highly susceptible to infection, is a classic example of the pivotal role that ROS plays in innate immunity. Mutations in NOX2 in neutrophils, impair phagocytosis as the respiratory burst is ineffective and hence these cells are unable to kill the invading pathogens [87]. In addition to NOX2, mitochondrial ROS has also been implicated in phagocytic bacterial lysis $[88,89]$. Bacterial activation of toll-like receptors (TLR1, TLR2 and TLR4) in macrophages increases mitochondrial ROS production and mitochondrial recruitment to the phagosome [89]. In addition, infection-induced endoplasmic reticulum stress increases mitochondrial ROS delivered to bacteria-containing phagosomes via mitochondria-derived vesicles (MDVs) [90].

ROS also plays important roles in the activation, proliferation and maturation of $B$ and T cells, key to adaptive immunity [91,92]. Both B and T cells express NOX2 [93-95], albeit at reduced levels compared to neutrophils and macrophages. Activated T cells directly contact and stimulate the respiratory burst of neutrophils [96], aiding in innate immunity. T-cell receptor (TCR) ligation triggers the production of NOX-derived ROS. Loss of NOX2 not only reduces ROS production but also alters cytokine production. In human T cells, the TCR stimulates ROS production through the activation of the NOX family member DUOX1, rescued by DUOX1 knockdown [97]. In addition to TCR stimulated ROS production in T cells, activation of CD28 which is necessary for T cell activation leads to ROS production and NF-kB induced interleukin-2 (IL-2) expression [98,99]. Mitochondrial ROS has also been shown to play an important function in T cell adaptive immune responses. Mitochondrial ROS induced by TCR-initiated calcium influx activates Nuclear factor of activated T cells (NFAT) to drive T cell activation and IL-2 production to drive antigen specific expansion in vivo and in vitro [92]. ROS are also involved the activation of B-cell receptors (BCR). High levels of ROS oxidatively inhibit phosphatases to activate BCR signalling further amplified through concomitant activation of Spleen tyrosine kinase (SYK) [100]. A recent study suggests that at the earlier stages of B cell activation, NOX2 is the main source of ROS, 
supplemented by mitochondrial ROS during immune response [101]. In addition, ROS has also been reported to increase the binding activity of PAX5, a transcription factor essential for B cell maturation. While molecular loss of Pax5 reduces B cell differentiation [102], alterations to PAX5 are seen in B-ALL [103].

\section{Redox Dysregulation in ALL}

Multiple lines of evidence support the notion that ROS play a role in the leukaemogenesis of ALL. ALL associated somatic heterogeneity and chromosomal translocations trigger constitutive activation of various oncogenic kinases, well-established contributors to increased ROS production in leukaemia [25]. Multiple pathways/mechanisms are involved in the generation of increased ROS in ALL (Figure 1). Some of the better characterised of these proteins/pathways are discussed below.

\subsection{ETV6/RUNX1 Fusions}

Hallmark ALL associated chromosomal abnormalities drive malignant transformation of HSCs and progenitor cells and are associated with increased ROS production. The common $\mathrm{t}(12 ; 21)$ (p13; $\mathrm{q} 22$ ) chromosomal translocations occurs in $25 \%$ of paediatric B-cell precursor ALL (BCP-ALL) and result in a chimeric ETV6/RUNX1 fusion gene [104]. ETV6/RUNX1 translocation has been reported prenatally to initiate a pre-leukaemic state [105]. This "first-hit" incidence of ETV6/RUNX1 fusion does not lead to malignant transformation; however, it can impair the function of wild type ETV6 and RUNX1, leading to cell cycle dysregulation [106]. Transgenic mouse models of ETV6/RUNX1 expressing CD19 ${ }^{+}$B cells, showed increased ROS and increased DNA damage [107]. Although the exact mechanism by which ETV6/RUNX1 increases ROS are not known, ETV6/RUNX1 binds with the promoter region of erythropoietin receptor (EPOR) to drive gene expression. Binding of EPO ligand with the EPOR in turn increases pre-B cell survival mediated by JAK2/STAT5 activity, which upregulates the antiapoptotic protein BCL-XL. Interestingly, NOX2-derived ROS in turn increases EPO signalling, suggestive of a positive feedback mechanism [108]. STAT5 binds and activates Rac1, promoting NOX mediated ROS production, to increase DNA damage in AML cell lines [30], a possible mechanism by which ETV6/RUNX1 induces ROS and garnishes the secondary hit necessary for preleukemic clones to propagate mutations that favour the development of fully transformed ALL.

\section{2. $B C R / A B L$ Oncogene}

An alternative $\mathrm{t}(9 ; 22)(\mathrm{q} 34 ; \mathrm{q} 11)$ translocation gives rise to the Philadelphia chromosome $(\mathrm{Ph})$, which is present in approximately $3 \%$ of paediatric, and in $25 \%$ of adult B-ALL $\left(\mathrm{Ph}^{+}\right.$ B-ALL) [109]. This translocation produces the Breakpoint cluster-Abelson (BCR/ABL) fusion protein, in which the tyrosine kinase domain of ABL1 becomes constitutively active. Interestingly, BCR/ABL has also been reported in healthy individuals [110], identifying this event as a putative first hit, but can transform cells by itself. Accordingly, BCR/ABL fusion protein activates multiple ROS producing signalling pathways, including PI3K/Akt/mTOR and JAK/STAT [111] (Figure 1). PI3K/Akt in turn increases ROS production through increased mitochondrial activity and NOX activation, [73] generating a positive feedback loop. BCR/ABL driven ROS [112], induces DNA damage and drug resistance [113]. Highlevel of ROS production in leukaemic blasts harbouring recurring BCR/ABL oncogenes is regulated by Rac independent activation of NOX4. BCR/ABL driven ROS can also oxidise and inhibit the tumour suppressor serine threonine phosphatase PP1 $\alpha$ leading to unfettered PI3K/Akt signalling and increased expression of proteins involved in cell survival [114]. The NOX and flavoprotein inhibitor diphenyleneiodonium (DPI), and tyrosine kinase inhibitors, Imatinib and Nilotinib, have both been shown to reduce ROS in preclinical models of BCR/ABL driven leukaemia [114,115]. Conversely, BCR/ABL transgenic mice express activated Rac3 in primary precursor B lymphoblasts, with molecular inhibition of Rac3 increasing survival of mice harbouring BCR/ABL+ leukaemia [116]. As Rac3 plays 
an important role in the activation of NOX1-3 [117], it is likely that BCR/ABL mutations increase Rac3-NOX mediated ROS production in ALL.

Not only does BCR/ABL influence redox signalling, but it also enhances the ability of cells to survive DNA damage by increasing expression of RAD51 and decreasing expression DNA protein kinase- DNA-PK (PRKDC), key elements of double-strand break (DSB) repair, homologous recombination repair (HRR) and non-homologous end-joining (NHEJ), respectively [118-121]. In cases of adult acute myeloid leukaemias (AML) driven by constitutive activation of the FMS-like tyrosine kinase 3 (FLT3) present in 30-35\% of cases [122]; Leukaemias well characterised by redox dysfunction [25], increased activity of the NHEJ DSBs repair pathway is also seen and regulated by the phosphorylation of S2612 DNA-PK [123].

\subsection{Cytokine Receptor-like Factor 2 (CRLF2)}

Approximately $20 \%$ of B-ALL patients harbour an activated kinase gene expression profile resembling $\mathrm{Ph}^{+} \mathrm{B}-\mathrm{ALL}$ but are negative for the BCR/ABL fusion [109]. Cytokine receptor-like factor 2 (CRLF2) encodes the receptor for thymic stromal lymphopoietin (TSLP), which activates cellular signalling on binding, required for normal lymphocyte function [124]. CRLF2 rearrangements lead to the overexpression of CRLF2 mRNA and protein [125] and are common in patients diagnosed with 'Ph-like' B-ALL [126]. Increased minimal residual disease (MRD) is frequently seen in Ph-like ALL patients following upfront standard induction chemotherapies, giving rise to disease relapse and poor overall survival [127]. Activation of CRLF2 stimulates PI3K/Akt/mTOR and JAK/STAT signalling to deregulate lymphoid progenitor differentiation, increases metabolism and, drives ROS production and associated genomic instability [82,128] (Figure 1). These studies suggest that CRLF2 induced ROS production can positively regulate its levels by constitutive activation of JAK/STAT signalling. Interestingly, the majority of Down syndrome (DS) patients who develop ALL (62\%) harbour increased CRLF2 expression, with genomic signatures enriched for increased DNA damage [129]. Approximately 50\% of Ph-like B-ALL patients with CRLF2-rearranged also harbour JAK1 or JAK2 mutations [125,130]. Overexpression of Crlf2 and mutant Jak2 drives factor-independent cell growth of murine BaF3 pro-B cells [129]. Furthermore, a recurring gain-of-function mutation in CRLF2 (F232C) seen in ALL patients, promotes constitutive dimerisation of the receptor, which may be induced by ROS, leading to cytokine independent activation and cell survival [131].

\subsection{Interleukin-7 Receptor $\alpha$ (IL7R)}

The Interleukin-7 receptor $\alpha(I L 7 R)$ is required for normal lymphoid development. Somatic gain-of-function mutations in $I L 7 R$ are seen in paediatric B and T -ALL. A S185C substitution in the extracellular domain or in-frame insertions and deletions in the transmembrane domain constitutively activates the IL7R [132]. IL7R mutations are dominantly linked with the aberrant expression of CRLF2, where mutant IL7R forms a functional receptor with CRLF2 for TSLP. Hence, IL7R signalling drives ROS production and redox dysfunction through the activation of PI3K/Akt/mTOR, JAK/STAT and ERK/MAPK pathways, all of which are implicated in ALL disease progression and treatment resistance [133-135].

\subsection{Transcription Factors PU.1 (SPI1) and Spi-B (SPIB)}

The E26-transformation-specific (ETS) transcription factors PU.1 (SPI1) and Spi-B $(S P I B)$ are important tumour suppressor genes that regulate $\mathrm{B}$ cell development and function [136,137]. Conditional deletion of Spi1 and Spi1B in pre-B-cells impairs B cell differentiation and drives ALL development through ROS production and acquisition of secondary driver mutations in JAK1, JAK3 or IKZF3 (IKAROS Family Zinc Finger 3). Acquired $J A K$ mutations can further promote leukaemia progression through hyperactivation of JAK/STAT signalling and further increased ROS production driving DNA damage [138]. Conversely, the JAK inhibitor, ruxolitinib, delayed leukaemia onset and suppressed both 
ROS production and ROS associated gene expression signatures [139]. Decreased levels of PU.1 increase HSCs cell cycle progression through the activation of the MAPK pathway [140]. MAPK increases the activity of Activator protein 1 (AP-1), a transcription factor driving expression of the NOX activating subunit $\mathrm{p} 22^{\text {phox }}$ creating a feed-forward loop [141].

\subsection{Neurogenic Locus Notch Homolog Protein 1 (NOTCH1)}

NOTCH1 signalling is the most (70-80\%) deregulated pathway in T-ALL [15]. NOTCH1 is a cell membrane receptor that plays a key role in the proliferation, differentiation, and activation of T cells. Mutations and constitutive activation of NOTCH1 in T-ALL promotes ROS production and PI3K/Akt signalling pathways indirectly through the regulation of C-myc [142], which in turn induces DNA damage [143] (Figure 1). PTEN, an upstream negative regulator of $\mathrm{PI} 3 \mathrm{~K} / \mathrm{Akt} / \mathrm{mTOR}$ suppresses and hence decreases ROS production. Importantly, ROS induce redox PTMs and inactivation of PTEN's tyrosine phosphatase activity leading to sustained activation of PI3K/Akt/mTOR and thus ROS production through a positive feedback mechanism in T-ALL (Figure 1). Furthermore, Casein kinase 2 (CK2), which positively regulates the PI3K/Akt/mTOR pathway, is also elevated in NOTCH1 mutant T-ALL, further increasing ROS production and hyperactivation of $\mathrm{PI} 3 \mathrm{~K} / \mathrm{Akt} / \mathrm{mTOR}$ signalling. It follows that combinations of the NAC antioxidant and the CK2 inhibitor tetrabromobenzotriazole (TBB) can synergistically ablate NOTCH1 driven T-ALL survival [144].

\subsection{Ras GTPases (N-and KRAS)}

Activating mutations in either $N$ - or KRAS are reported in 15-20\% the paediatric ALL [145-147], and are enriched in relapsed and chemo resistant ALL patients [148]. Increased expression or activity of RAS guanyl-releasing protein 1(RASGRP1), a positive regulator of RAS/Raf/MEK pathway also occurs in ALL $[149,150]$. RAS proteins function as molecular switches that cycle between active and inactive states based upon the binding of guanosine triphosphate (GTP) and guanosine diphosphate (GDP), respectively. Normally, ligand mediated RTK activation is required to stimulate RAS and initiate a cascade of Raf/MEK signalling responsible for regulating multiple cellular functions including protein trafficking, ROS production and cellular proliferation $[28,151]$. However, mutations in codons 12, 13 and 61 impair the GTPase activity, constitutively activating RAS proteins and hence the downstream Raf/MEK pathway driving tumour growth [152]. Through the stimulation of NOX, constitutively active N-Ras ${ }^{\mathrm{G} 12 \mathrm{D}}$ and H-Ras ${ }^{\mathrm{G} 12 \mathrm{~V}}$ upregulate ROS production promoting growth-factor independent proliferation of human CD34 ${ }^{+}$ haematopoietic cells. Mechanistically, K-RAS activates p38 MAPK initiating a cascade of PDPK1/PKC / p47 phox /NOX1 signalling for the generation of ROS and cellular transformation (Figure 1). Given the role of RAS in NOX-induced ROS and recurring RAS lesions [24,145-147], it is very likely that constitutively active RAS drives ROS production in ALL, and as such patients may benefit from therapies targeting this ROS production pathway (discussed in Section 6). Indeed, MEK inhibition, a downstream target of RAS, synergises with prednisolone in the treatment of both RAS-mutant and wildtype ALL [153], potentially underpinned by reduced ROS production following RAS inhibition.

\subsection{Rho-Family GTPases}

The increased expression and activation of Rho GTPase family proteins RAC1-3 is common in ALL $[116,154,155]$. Like Ras, Rac GTPases also cyclically switch between GTP-bound active and GDP-bound inactive states. While Rac1 regulated the chemotactic response of ALL cells to chemokine SDF-1 $\alpha$ (CXCL12) produced by stromal cells [156], molecular inhibition of Rac3 prolonged the survival of mice with BCR/ABL induced leukaemia [116]. Similarly, central nervous system metastatic pre-B leukaemia cells (SD1cells) overexpress Rac2, and when pre-treated with the Rac inhibitor, NSC23766, prior to engraftment, delayed disease establishment and significant reduction in leukaemia 
burden in extramedullary organs and the cranium [154]. The tetraspanin family member, CD9, is also reported to activate Rac1 and form cytoplasmic extensions and homing of B-ALL cells in vivo and in vitro [157]. Although the direct role of Rac proteins in ROS production has not been discussed, their reported role in NOX1-3 activation $[117,158]$ raises the prospect that they may contribute to NOX mediated ROS production in ALL; an intriguing possibility that warrants further exploration.

\subsection{NAD $(P) H$ Quinone Dehydrogenase 1 (NQO1)}

The $\mathrm{NAD}(\mathrm{P}) \mathrm{H}$ :quinone oxidoreductase 1 (NQO1) is a cytosolic two-electron oxidoreductase, detoxification and cytoprotective enzyme that protects cells against oxidative stress $[159,160]$. This enzyme functions as a superoxide reductase to generate antioxidant forms of ubiquinone and vitamin $\mathrm{E}$ to protect cells against oxidative stress. A polymorphism (C609T) in the NQO1 gene leads to loss of protein expression, and hence loss of downstream ROS detoxification, with heterozygous $(\mathrm{C} / \mathrm{T})$ and homozygous $(\mathrm{T} / \mathrm{T})$ alleles reducing and abolishing reductase activity, respectively [161-163]. Studies report the increased association of low/null NQO1 activity and increased risk of infant ALL [162,164]. The loss/reduction in reductase activity is potentially associated with in utero genotoxic stress elicited through various oxidative cascades that accompany foetal haematopoiesis in the yolk sac from where it migrates to form part of the foetal bone marrow [165]. Conversely, overexpression of NQO1 is cytoprotective, and known to drive metastasis [166], with overexpressed NQO1 commonly detected in late stage and poor prognoses cancers [167]. Depletion of NQO1 sensitised treatment-recalcitrant non-small cell lung cancers to low-dose radiotherapy by decreasing the cells reductase activity and increasing the genotoxicity of ionising radiation [168]. Furthermore, knockdown of NQO1 in immune checkpoint inhibitor resistant tumours increased innate immune response to stimulate antitumour $\mathrm{T}$ cell adaptive immunity, and when retreated with checkpoint blockade therapies, eradicated therapy-resistant tumours [27].

\section{Redox Homeostasis in ALL}

ALL cells have evolved several compensatory mechanisms to ensure that ROS production does not induce irreversible DNA damage and cell death [169] (Figure 1). Many of these mechanisms centre on the expression of antioxidant systems with, for example, the gene and protein levels of thioredoxin reductase 1 (TXNRD1), TXN1 and PRDX1 all being elevated in B-ALL cell lines and primary patient samples [170]. Similarly, although $\mathrm{H}_{2} \mathrm{O}_{2}$ is usually a key signal in dexamethasone-induced apoptosis, pre-B-ALL cells that display dexamethasone resistance are characterised by overexpression of GSH; yet can be re-sensitised using L-buthionine-(S, R)-sulfoximine (BSO), an inhibitor of GSH synthesis [171]. Furthermore, thymic lymphoma cells that overexpress catalase are also resistant to dexamethasone [172]. As previously noted, manganese superoxide dismutase (MnSOD) overexpression drives $\mathrm{H}_{2} \mathrm{O}_{2}$ production and thus sensitises thymic lymphoma cells to dexamethasone via the release of mitochondrial cytochrome $\mathrm{c}$ and activation of caspases [173]. Importantly, increased GSH expression is associated with the increased risk of relapse in children diagnosed with ALL [174]. High-level expression of GPx1 is also seen in ALL, influenced by decreased expression of $m i R-491-5 p$ and $m i R-214-3 p$ via VPS9D1 antisense RNA 1 [175]. Knockdown of GPx1 reduced proliferation and activated apoptosis, with the VPS9D1 antisense RNA 1 acting as a tumour promoter to increase GPx1 expression and decrease $m i R-491-5 p$ and $m i R-214-3 p$.

Regardless of the subtype, nuclear factor- $\mathrm{kB}(\mathrm{NF}-\mathrm{kB})$ complexes show constitutive activation in paediatric ALL $[176,177]$. NF- $\mathrm{KB}$ proteins are a family of transcription factors that regulate immune responses to pathogens, inflammation, promote growth and proliferation, and cell development [178]. Indeed, NF- $\mathrm{kB}$ transcription factors are responsible for the expression of the ROS producing NADPH oxidase enzymes [179] (discussed in Sections 3, 5.2, 5.7, 5.8 and 7.2) but can also upregulate the expression of antioxidants (reviewed in [60]). Not only does NF- $\mathrm{kB}$ activity increase NADPH oxidase expression and 
hence ROS production, but ROS regulates the transcriptional activity of NF- $\mathrm{KB}$ through degradation of the NF- $\kappa B$ inhibitory protein I $\kappa \mathrm{B}$, promoting nuclear translocation and transcription of $\kappa B$ genes, creating both a feed-forward and positive feedback loop $[180,181]$. Potentially, the chronic activity of PI3K-Akt signalling driven by recurring ALL associated somatic mutations (BCR/ABL, IL7R/CRLF2), may help to initiate the NF- $\kappa B$ positive feedback loop. Akt activates I $\kappa \mathrm{B} \alpha$ kinase (IKK) and p38 MAPK leading to the phosphorylation and degradation of IKB [182]. Loss of PTEN expression further potentiates NF-kB activity through unfettered PI3k/Akt signalling driving the activity of IKK, and further degradation of IKB, supressing apoptosis [183] and driving resistance to doxorubicin [184].

The observations that NF- $\mathrm{kB}$ acts an oncogene in ALL, contrasts with pre-B-ALL studies suggesting NF- $\mathrm{KB} 1$ is a tumour suppressor. The ratio of phosphorylated and hence nuclear translocated STAT5 to RELA expression (NF- $\mathrm{KB}$ transcriptional effector) correlates with B-ALL patient survival and disease remission [185]. Competition between STAT5 and NF- $\mathrm{KB}$ for common binding sites increased expression of STAT5 genes including Cyclin D2 and D3 (CCND2, CCND3) and the oncogene MYC (MYC) [185], driving an aggressive form of B-ALL. As there is no doubt that STAT5 plays a critical role in the leukaemogenesis of $B$ and $T$-ALL, with its activity required for transformation downstream of ALL oncogenes [186-188], it is interesting to postulate the direct roles ROS plays in the activity of STAT5 and vice versa. Like NF-kB, STAT5 enhances transcription of the NOX (specifically NOX4). By doing so, STAT5 promotes increased ROS production which acts as a feed-forward loop. However, it is unknown whether the activity of STAT5 plays a direct role in NOX complex activation in ALL. In AML, phosphorylated STAT5 has also been shown to co-localise with Rac1, suggesting a mechanism in which phosphorylated STAT5 promotes ROS production by NOX. Given Rac1 is overexpressed in primary ALL and AML primary blasts compared to controls [189], and pharmacological inhibition of Rac1 is selectively cytotoxic to primary ALL cells and not on normal lymphocytic cells [190], it is indeed possible that the high-level activity of STAT5 in ALL may promote Rac1-induced NOX activity helping to form a feed-forward loop analogous to AML.

There is clear evidence of oxidative dysfunction in ALL. However, to ensure ROS accumulation does not exceed the tipping point and shift from their leukaemogenic roles to induction of regulated cell death pathways, these malignant cells hijack homeostatic mechanisms for survival. The Nuclear factor-erythroid factor 2-related factor 2- NRF2 (NFE2L2), a transcription factor negatively regulated by Kelch-like ECH-associated protein 1 (KEAP1) under basal conditions. ROS mediated redox cysteine PTMs induce conformational changes in KEAP1, leading to the release and subsequent translocation of NRF2 to the nucleus. Within the nucleus, NRF2 binds to antioxidant response element loci located at the promoters of multiple genes that orchestrate cytoprotection through rapid expression of NQO1 (discussed in Section 5.9), combatting oxidative stress and driving cell survival [191,192]. A recent study showed 73\% of paediatric ALL patients $(22 / 30)$ harboured nucleotide changes in genes mapping to the KEAP1/NRF2/NF-kB1/p62 pathway [193]. The significant functional crosstalk between NF-KB and NRF2 suggests that both play important roles in the oxidative dysfunction of ALL cells. It is interesting to note that ALL cells are afforded protection against standard induction chemotherapies via interaction with neighbouring adipocytes [194]. In this regard, daunorubicin treatment of ALL cells has been shown to dramatically upregulate NRF2-mediated oxidative stress response in adipocyte co-cultures and protect ALL cells from genotoxic stress. Such data implies that ALL cells induce oxidative stress in adipocytes through yet an unknown mechanism. Blocking GSH synthesis in adipocytes subsequently re-sensitises ALL cells to daunorubicin, suggesting adipocyte secreted exogenous antioxidants protect ALL cells from chemotherapy [195]. In a similar context, mesenchymal stem cells (MSCs) found in bone marrow release thiols (antioxidant) to protect T-ALL cells from parthenolide induced oxidative stress [196].

In addition to intracellular factors, ALL cells have been reported to make direct contact with the bone marrow stromal cells via tunnelling nanotubes (TNTs); long cylindrical 
non-adherent actin-based cytoplasmic extensions that play an important role in direct communication and transfer of macromolecules between adjacent cells [197]. Recently, Jurkat ALL cells were reported to directly transfer mitochondria to the bone marrow stromal cells via TNTs upon exposure to chemotherapeutic drugs, thereby reducing ROS induced cellular death [198]. Furthermore, primary patient derived pre-B-ALL cells signal to the bone marrow stromal cells through TNTs, driving secretion of pro-survival cytokines such as interferon- $\gamma$-inducible protein 10/CXC chemokine ligand 10 (CXCL10), IL-8, and monocyte chemotactic protein-1/CC chemokine ligand (CCL2) causing resistance to prednisolone [199].

T-ALL switch their metabolic programs in a similar way to normal HSCs when cultured in low oxygen [200]. Reduced mitochondrial activity and cell cycle progression in these low oxygen niches increases glycolysis and lowers their sensitivity to vincristine and cytarabine (cell cycle-related drugs) and dexamethasone, compared with T-ALL cells grown under normoxic conditions [201]. While low oxygen levels suppressed the activity of mTORC1, it increased the activity of HIF1 $\alpha$ with the concomitant increase in the expression of HIF $1 \alpha$ effector genes such as, VEGF, GLUT3 and CXCR4 to reduce mitochondrial activity and as such ROS levels in ALL [201].

In contrast, B-ALL cells seem to rely more on oxidative phosphorylation and mitochondrial activity than T-ALL [34]. B-ALL cells with reduced NADP/NAD ${ }^{+}$ratios were enriched for functional leukaemia-initiating cells (LICs) resistant to cytosine arabinoside (Ara-C) [34]. These cells maintained their oxidative stress levels and resistance to Ara-C through the activation of pyruvate dehydrogenase complex component $\mathrm{X}$ (PHDX). Further, Ara-C resistance was attenuated by suppressing oxidative phosphorylation using venetoclax, metformin, and berberine, inhibitors of mitochondrial metabolism in vitro and in vivo [34].

Autophagy is another mechanism that aids leukaemic cells to survive oxidative stressinduced apoptosis. By way of example, ROS have been shown to induce the expression of Beclin-1 (BECN1) (an autophagy related protein with an essential role in autophagosome formation) and increase the removal of injured mitochondria to drive chemotherapy resistance in ALL [202,203]. Importantly, quinacrine (QC) (an anti-malaria drug that potently inhibits autophagy) in combination with vorinostat (a pan-histone deacetylase (HDAC) inhibitor), significantly increased ROS production, which reduced autophagy and caused synergistic apoptosis in T-ALL cells [204].

\section{The Modulation of ROS to Target ALL}

\subsection{Pro-Oxidant Therapies}

The importance of ROS in driving the leukaemogenesis of ALL highlights the potential for modulating the redox balance of malignant $\mathrm{B}$ or $\mathrm{T}$ lymphoblasts to improve treatment. Given their characteristically high-ROS chemotype and dysregulated antioxidant system, further redox modulation is an effective strategy to eliminate ALL blasts (Figure 2) [205]. Accordingly, many therapeutics used in the treatment of ALL increase oxidative stress. For example, the antimetabolite methotrexate, microtubule inhibitor vincristine, and DNA damaging agents such as doxorubicin, daunorubicin and cytarabine drive oxidative stress [206-209]. However, to enhance the therapeutic benefit of these strategies, simultaneous modulation of the antioxidant system such as NRF2 (discussed in Section 6) may be necessary to decrease resistance and reduce clonal evolution.

As mentioned above, dexamethasone works by binding to the glucocorticoid receptor driving ROS production via the endoplasmic stress pathway and ultimately causing DNA DSBs and error-prone repair [210,211]. Multiple other targeted therapies have been implicated in modulating the redox system to induce apoptosis including the Bcl-2 inhibitor venetoclax [212], HDAC inhibitor vorinostat [213], antimalarial drug quinacrine (QC) [204], antidiabetic drug metformin [214], $\mathrm{Ca}^{+}$and $\mathrm{K}^{+}$channel activator NS1619 (benzimidazolone) [215], TXNRD1/2 inhibitor auranofin (AUR) [216], PRDX1/2 and TXN1 inhibitor adenanthin (ADE) [170] (Table 1 and Figure 2). 


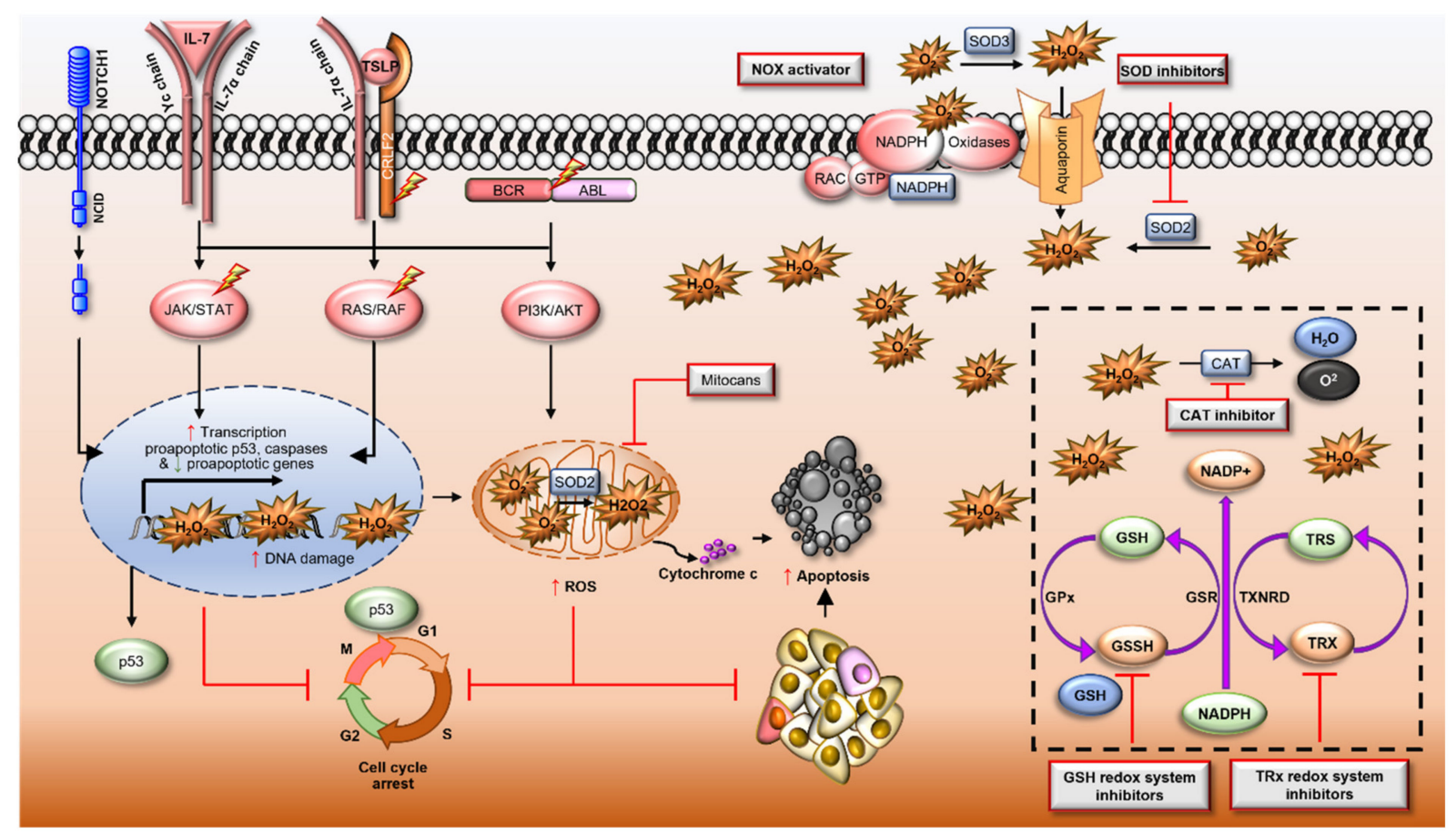

Figure 2. Pro-oxidant therapies for the treatment of acute lymphoblastic leukaemia. Pro-oxidant therapies such as chemotherapies cause redox dysfunction driving irreversible genotoxic stress and are linked to increased activity of NOX proteins. Mitocans target the mitochondrial electron transport chain, increase the permeability of mitochondrial membranes, increasing cytoplasmic ROS. High-level ROS production increases expression and activity of pro-apoptotic proteins such as p53 and caspases, inducing cell cycle arrest, releasing cytochrome c and inducing apoptosis in leukaemic cells. The molecular targets and mechanisms of drugs enhancing ROS production are listed in Table 1 . Red shapes = proteins with increased activity or expression; lightning bolt = proteins harbouring mutations / translocations; orange = oxidised proteins; light green $=$ reduced proteins.

Table 1. Pro-oxidant therapies used in the pre-clinical models of various cancers.

\begin{tabular}{|c|c|c|c|}
\hline $\begin{array}{l}\text { Drug } \\
\text { (Status) }\end{array}$ & $\begin{array}{l}\text { Signalling } \\
\text { Pathways }\end{array}$ & Possible Mechanism of Action & References \\
\hline $\begin{array}{c}\text { Arsenic trioxide } \\
\text { (FDA approved drug for AML) }\end{array}$ & $\begin{array}{l}\text { Mitochondrial } \\
\text { membrane } \\
\text { NOX2 }\end{array}$ & $\begin{array}{c}\uparrow \text { ROS by inhibiting reducing GSH } \\
\text { expression, and inhibiting GPx, GST and } \\
\text { catalase activity, and increasing NOX2 } \\
\text { expression and activity }\end{array}$ & {$[217,218]$} \\
\hline Doxorubicin & Mitochondria & $\begin{array}{c}\uparrow \text { ROS due to topoisomerase-II } \beta \\
\text { transcriptome mediated loss of } \Delta \Psi \mathrm{m}\end{array}$ & [219] \\
\hline $\begin{array}{c}\text { Tigecycline } \\
\text { (FDA approved drug for disease other than } \\
\text { cancer other disease) }\end{array}$ & Mitochondria & $\begin{array}{l}\uparrow \text { ROS by suppressing the translation of } \\
\text { complex I and IV of mitochondrial proteins }\end{array}$ & [220] \\
\hline $\begin{array}{c}\text { NOV-002 } \\
\text { (In Clinical trials for Myelodysplastic } \\
\text { Syndrome (MDS) and NSLC) }\end{array}$ & Redox enzymes & $\begin{array}{l}\uparrow \text { ROS by acting as GSSG mimetic } \\
\text { Also stimulates blood cell production }\end{array}$ & [221] \\
\hline $\begin{array}{c}\text { 2-methoxyestradiol (Panzem) } \\
\text { (FDA approved drug for multiple cancers } \\
\text { including meyloma) }\end{array}$ & Redox enzymes & $\begin{array}{l}\uparrow \text { ROS by inhibiting Superoxide } \\
\text { dismutases (SODs) }\end{array}$ & [222] \\
\hline $\begin{array}{c}\text { ATN-224 } \\
\text { (Completed phase } 2 \text { clinical trials for MM } \\
\text { and prostate cancer) }\end{array}$ & Redox enzymes & $\begin{array}{l}\uparrow \text { ROS by inhibiting copper/zinc } \\
\text { SOD activity }\end{array}$ & [223] \\
\hline $\begin{array}{c}\text { Imexon } \\
\text { (Completed phase } 2 \text { clinical trials for } \\
\text { multiple myeloma and lymphoma) }\end{array}$ & Redox homeostasis & $\uparrow$ ROS by reducing cysteine and GSH pool & [224] \\
\hline
\end{tabular}


Table 1. Cont.

\begin{tabular}{|c|c|c|c|}
\hline $\begin{array}{c}\text { Drug } \\
\text { (Status) }\end{array}$ & $\begin{array}{l}\text { Signalling } \\
\text { Pathways }\end{array}$ & Possible Mechanism of Action & References \\
\hline $\begin{array}{c}\text { PX-12 } \\
\text { (Completed phase } 2 \text { clinical trials to treat } \\
\text { solid tumours) }\end{array}$ & Redox enzymes & $\begin{array}{l}\uparrow \text { ROS by inhibiting thioredoxin } \\
\text { enzymes system }\end{array}$ & {$[225,226]$} \\
\hline $\begin{array}{c}\text { Parthenolide and derivatives } \\
\text { (Natural compound) } \\
\text { (Phase I/II studies for various cancers) }\end{array}$ & Thiol inhibitors & $\begin{array}{l}\uparrow \text { ROS by depleting cellular thiol } \\
\text { including GSH }\end{array}$ & [227] \\
\hline BSO (L-buthionine-(S,R)-sulfoximine (BSO) & Redox system & $\uparrow$ ROS by depleting GSH & [228] \\
\hline TPEN (zinc chelator) & Redox System & $\begin{array}{c}\uparrow \text { ROS and induces loss of } \Delta \Psi \mathrm{m} \text { by } \\
\text { unknow mechanism }\end{array}$ & {$[229,230]$} \\
\hline $\begin{array}{l}\text { Cannabidiod CP55940 } \\
\text { (Natural compound) }\end{array}$ & Redox system & $\uparrow \operatorname{ROS}$ loss $\Delta \Psi \mathrm{m}$ and $\mathrm{Ca}^{2+}$ overload & [231] \\
\hline $\begin{array}{c}\text { Curcumin } \\
\text { (Natural compound) }\end{array}$ & Mitochondria & $\uparrow$ ROS loss of $\Delta \Psi \mathrm{m}$ by unknow mechanism & [232] \\
\hline Vinblastine & Redox system & $\uparrow$ ROS by depleting GSH levels & [233] \\
\hline $\begin{array}{l}\text { Quercetin } \\
\text { (Natural compound) }\end{array}$ & Mitochondria & $\begin{array}{c}\uparrow \text { ROS by depleting GSH levels and } \\
\text { inducing loss } \Delta \Psi \mathrm{m}\end{array}$ & [234] \\
\hline $\begin{array}{l}\text { Erastin } \\
\text { (eradicator of RAS and ST) } \\
\text { Auranofin }\end{array}$ & Redox system & $\begin{array}{l}\uparrow \text { ROS by inhibiting and Cys } 2 \text { /glutamate } \\
\text { antiporter leading glutathione depletion }\end{array}$ & [235] \\
\hline $\begin{array}{l}\text { (FDA approved drug to treat } \\
\text { rheumatoid arthritis) }\end{array}$ & Redox enzyme & $\uparrow$ ROS by inhibiting TXNRD & [236] \\
\hline $\begin{array}{l}\text { Adenanthin (ADE) } \\
\text { (Natural compound) }\end{array}$ & Redox enzymes & $\uparrow$ ROS by inhibiting PRDX1/2 activities & [237] \\
\hline RSL3 (RAS-synthetic-lethality 3) & Redox enzymes & $\begin{array}{l}\uparrow \text { ROS by inhibiting GPX4 and } \\
\text { induce ferroptosis }\end{array}$ & [238] \\
\hline $\begin{array}{c}\text { Matrine } \\
\text { (Natural compound) }\end{array}$ & Mitochondria & $\begin{array}{l}\uparrow \text { ROS, loss } \Delta \Psi \mathrm{m} \text { and mitochondrial } \\
\text { swelling by unknow mechanism }\end{array}$ & [239] \\
\hline NS1619 & Mitochondria & $\uparrow$ ROS production by unknow mechanism & [215] \\
\hline Adaphostin & Mitochondria & $\begin{array}{c}\uparrow \mathrm{ROS} \text { and loss of } \Delta \Psi \mathrm{m} \text { by inhibiting } \\
\text { mitochondrial respiration }\end{array}$ & [240] \\
\hline $\begin{array}{c}\text { APR-246 } \\
\text { (Phase I clinical trials) }\end{array}$ & Redox enzymes & $\uparrow$ ROS by inhibiting TRX1 and glutaredoxin & [241] \\
\hline $\begin{array}{l}\text { Sanguinarine } \\
\text { (Natural compound) }\end{array}$ & Mitochondria & $\begin{array}{c}\uparrow \mathrm{ROS} \text { and loss of } \Delta \Psi \mathrm{m} \text { by depleting } \\
\text { glutathione }\end{array}$ & [242] \\
\hline $\begin{array}{c}\text { Alantolactone } \\
\text { (Natural compound) }\end{array}$ & & $\begin{array}{l}\uparrow \text { ROS by inhibiting glutathione } \\
\text { reductase (GR) }\end{array}$ & [243] \\
\hline CB-839 & Redox enzyme & $\begin{array}{l}\uparrow \text { ROS by inhibiting glutaminase to } \\
\text { suppress glutathione production }\end{array}$ & [244] \\
\hline $\begin{array}{l}\text { 6-Shogaol } \\
\text { (Natural compound) }\end{array}$ & $\begin{array}{l}\text { Unknown } \\
\text { mechanism }\end{array}$ & $\uparrow$ ROS by reducing GSH & {$[245,246]$} \\
\hline
\end{tabular}

Note: the list is not exhaustive. $\triangle \Psi \mathrm{M}$, mitochondrial membrane potential; TRX, thioredoxin; GRX, TXNRD; thioredoxin reductase; $\uparrow$, increase.

A by-product of mitochondrial oxidative phosphorylation is ROS production [247]. Therefore, mitochondrial electron transport chain complexes represent logical targets for leukaemia specific therapies. One such class of drugs are the mitocans that target the mitochondria of cancer cells [248], and include tigecycline an FDA-approved agent that has shown promising anti-leukaemic results through decreased fidelity of the mitochondrial respiratory complexes I and IV, driving oxidative stress, DNA damage, and apoptosis [220,249] (Figure 2). Alternatively, the imipridones ONC201, ONC206 and ONC212 bind with, and activate mitochondrial caseinolytic protease P ClpP (CLPP), a protease that degrades misfolded proteins within the mitochondria. Activation of $\mathrm{ClpP}$ has been shown to drive selective degradation of respiratory chain protein substrates and disrupt membrane potential $(\Delta \Psi \mathrm{m})$ resulting in increased mitochondrial ROS and apoptosis in Z-138 lymphoma cells [250]. Our own unpublished data shows ONC201 is highly effective in inducing apoptosis in primary ALL blasts. Building on these observations, analogues of 
vitamin E such as $\alpha$-tocopheryl succinate ( $\alpha$-TOS), can inhibit the succinate dehydrogenase $(\mathrm{SDH})$ activity of complex II (CII), thereby inducing ROS production and driving apoptotic cascades [251]. Similarly, D- $\alpha$-tocopheryl polyethylene glycol 1000 succinate (TPGS), has been reported to induce oxidative stress by modulating mitochondrial membrane potential resulting in apoptosis [252]. Some mitocans are in clinical trials, while others already have FDA approval [248].

Various natural compounds have also been reported to increase ROS production in cancer cells. Resveratrol (a phenol found in relatively high concentration in berries) and curcumin (obtained from turmeric) are two well-known examples of such compounds. Resveratrol has been reported to reduce $\Delta \Psi \mathrm{m}$, driving caspase activity and cell death in ALL [253,254]. Similarly, curcumin elevates intracellular ROS through binding and possibly modulating the activities of antioxidant enzymes in leukaemia [255]. Curcumin-induced apoptosis in a panel of ALL cell lines via inhibition of PI3K/Akt signalling increased ROS production and release of pro-apoptotic cytochrome c protein. Further, suboptimal doses of curcumin has been shown to enhance the anticancer activity of cisplatin [232]. A range of other natural anticancer compounds, together with their mode of action, are listed in Table 1.

\subsection{Therapies to Reduce ROS}

Pro-oxidant therapies are effective anti-ALL treatments, however, work by increasing global oxidative stress and hence tend to be very non-specific. Given the dynamic redox-balance of HSCs; it is challenging to employ a pro-oxidative treatment approach in leukaemia without causing systemic toxicities [147].

An alternative strategy is to reduce the activity of oxidase enzymes responsible for ROS production, and or target the signalling pathways that drive the activity/expression of these oxidases (Figure 3). For example, azelaic acid (ZA) is a natural compound that inhibits tyrosinase, cytochrome-P450 reductase and respiratory chain enzymes, thereby suppressing the production and actions of ROS. Illustrative of this, ZA increased the expression of PRDX2/PRDX3 antioxidant enzymes, driving cell cycle arrest at G1 and apoptosis in AML cells in vitro and in vivo [256]. Similarly, metformin, has been shown to induce cytotoxicity in cancer cells by decreasing ROS levels and suppressing mitochondrial ATP synthesis; a response attributed to metformin's inhibition of mitochondrial respiratory complex I (CI) [214]. Nevertheless, to date no clinical trials have employed antioxidant therapies alone or in combination to specifically treat ALL.

In contrast to ROS produced as a by-product of metabolism, NOX enzymes produce ROS as a primary function in response to infection [25] or to drive angiogenesis following hypoxia [257]. Further, NOX has been implicated in tumour progression [134,258-261], leukaemic stem cell (LSC) self-renewal [32] and resistance to therapies [262]. Cell lines harbouring FLT3 internal tandem-duplication (FLT3-ITD) mutations, showed increased expression and activity of NOX2 linked with elevated ROS-associated DNA damage. Partial knockdown of the transcription factor STAT5 (STAT5A and STAT5B) in FLT3-ITD cells resulted in decreased ROS production [263], highlighting the oncogenic association between recurring somatic mutations and the necessity for leukaemia cells to maintain a state of oxidative dysfunction.

Due to the emerging role of NOX in various cancers, targeting of NOX alone or in combination with the other therapies is gaining popularity as a treatment paradigm [264-266]. Genetic or pharmacological (GKT137831) inhibition of NOX4 reduced cancer associated fibroblasts growth and survival [243] and metastasis of non-small cell lung cancer cells in vivo and in vitro [266], and potentiated sensitivity to immunotherapy in murine lung cancer models [265]. Similarly, genetic/chemical inhibition of NOX suppressed the growth of gastric [261], colon [267], skin [268], liver [269] and human granulosa-lutein and granulosa [270] tumours. 


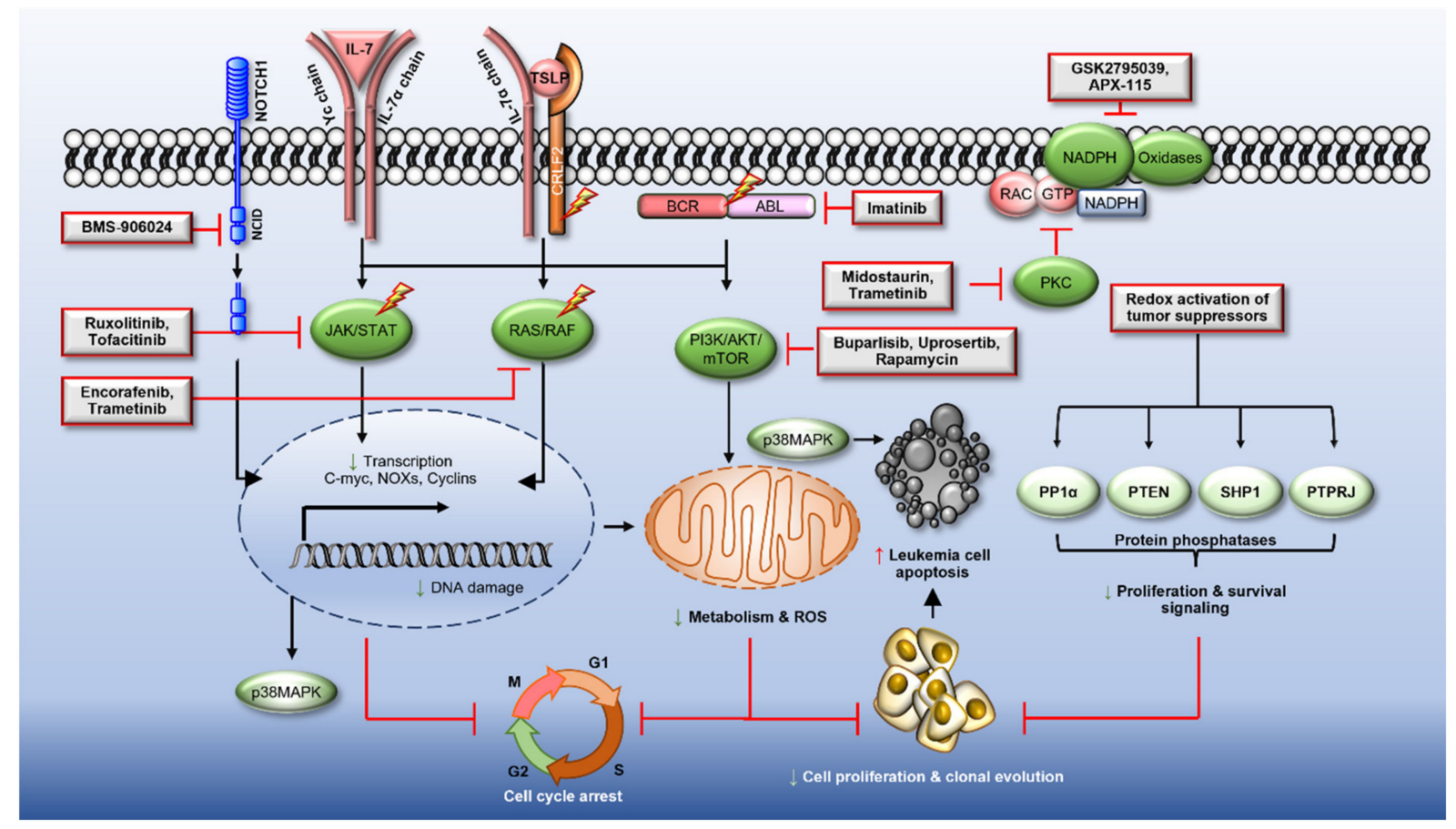

Figure 3. Therapeutic strategies targeting reactive oxygen species production for the treatment of acute lymphoblastic leukaemia. Therapies targeting oncogenic kinases in acute lymphoblastic leukaemia (ALL) reduce ROS production. NOX inhibitors (NOXi) used in combination with targeted therapies synergise with ALL tyrosine kinase inhibitors (TKIs) or kinase inhibitors (KIs) and are emerging as a novel therapeutic strategy. Red shapes = proteins with increased activity or expression; dark green shapes $=$ decreased activity or expression; lightning bolt = proteins harbouring mutations/translocations; orange = oxidised proteins; light green = reduced proteins.

Given the increased expression and/or activity of NOX (discussed in Section 3), targeting NOX is a potential therapeutic approach particularly for ALL blasts residing within the hypoxic bone marrow niche $[114,115,134]$. Importantly, NOX2 derived ROS has been reported to promote transfer of mitochondria from the bone marrow stromal cells to the leukaemic cells via TNTs [271]. Therefore, combining NOX inhibition with standard of care chemotherapies may be an effective strategy to target blasts and LICs/LSCs protected by the bone marrow, to overcome the potential of drug resistance [271] (Figure 3). Multiple compounds have been reported to inhibit NOX enzymes and promisingly, some of these compounds are already in clinical trials to treat various clinical conditions [272-274] (Table 2). For example, NOX proteins drive oxidative stress and multiple organ damage exacerbating diabetic complications such as diabetic retinopathy, nephropathy, neuropathy, disorders of the cardiovascular system [275] and acute pancreatitis [276]. It follows that NOX inhibitors such as GKT137831 (NOX1 and NOX4 inhibitor), APX-115 (pan NOX and DUOX inhibitor) and GSK2795039 (NOX2) have shown promising results in preclinical mouse models of disease [274,277-280], with some currently in clinical trials (Table 2).

Despite promising results in preclinical tumour models, including ALL, no clinical trials are yet evaluating the efficacy of NOX inhibition to treat cancer either alone or in combination. In taking up this challenge, unpublished work from our own group shows the potential of NOX inhibitors (GSK2795039 and APX-115) used in combination with tyrosine kinase inhibitors to target 'kinase-active' ALL cells in vitro and in vivo (unpublished data). Given that at least some NOX inhibitors are already in clinical trials for other indications, studies that provide much needed safety and/or tolerability data, targeting NOX is the natural next step in the development of new ALL treatment regimens. 
Table 2. NOX inhibitors.

\begin{tabular}{|c|c|c|c|c|}
\hline Drug & $\begin{array}{c}\text { Possible Mechanism } \\
\text { of Action }\end{array}$ & Impact on NOX & Experimental Model & References \\
\hline $\begin{array}{c}\text { Normobaric oxygen (NBO) } \\
\text { and Hyperbaric oxygen } \\
(\mathrm{HBO})\end{array}$ & Unknown & $\begin{array}{c}\text { NOX2 levels and activity } \\
\text { downregulation }\end{array}$ & Male Sprague-Dawley rats & {$[281,282]$} \\
\hline Ethanol & Unknown & $\begin{array}{l}\text { Reduced activity enzyme } \\
\text { and gp91 expression }\end{array}$ & Rat model of ischemia & [283] \\
\hline $\begin{array}{l}\text { PKC inhibitors (Calphostin } \\
\text { C, Chelerythrine and } \\
\text { Ruboxistaurin mesylate) }\end{array}$ & $\begin{array}{l}\text { Inhibiting PKC mediated } \\
\text { p } 47^{\text {phox }} \text { phosphorylation }\end{array}$ & Reduced activity of NOX & $\begin{array}{c}\text { Human } \\
\text { polymorphonuclear } \\
\text { leukocytes }\end{array}$ & [284] \\
\hline $\begin{array}{l}\text { Diphenylene iodonium } \\
\text { (DPI) }\end{array}$ & $\begin{array}{l}\text { Forms redox adduct with } \\
\text { the NOX catalytic core }\end{array}$ & $\begin{array}{l}\text { Reduced NOX } 1 \\
\text { expression }\end{array}$ & $\begin{array}{l}\text { Human colon carcinoma } \\
\text { cells in vivo and in vitro }\end{array}$ & [285] \\
\hline $\begin{array}{c}\text { Apocynin } \\
\text { (4-hydroxy-3methoxy- } \\
\text { acetophenone), natural } \\
\text { compound) }\end{array}$ & $\begin{array}{l}\text { Blocks p47 }{ }^{p h o x} \text { cell } \\
\text { membrane migration and } \\
\text { NOX assembly }\end{array}$ & $\begin{array}{c}\text { Inhibit assembly and } \\
\text { activity of NOX1 and } \\
\text { NOX2 }\end{array}$ & Human neutrophils & [286] \\
\hline VAS2870 (Vasopharm), & $\begin{array}{l}\text { Upregulation of NOX2 } \\
\text { and } 4 \text { targeting } \\
\text { microRNA }\end{array}$ & $\begin{array}{l}\text { Reduced expression of } \\
\text { NOX2 and Nox } 4\end{array}$ & Rat model of ischemia & [287] \\
\hline Celastrol & $\begin{array}{l}\text { Disrupt NOX enzyme } \\
\text { assembly }\end{array}$ & $\begin{array}{l}\text { Binds to } \mathrm{p} 47^{\text {phox }} \text { and } \\
\text { disrupted } \mathrm{p} 22^{\text {phox }}\end{array}$ & $\begin{array}{l}\text { Human neutrophils, } \\
\text { HEK293 and CHO in vitro } \\
\text { and cell free assays }\end{array}$ & [288] \\
\hline $\begin{array}{l}\text { NOX peptide inhibitors } \\
\quad \text { (e.g gp91ds-tat) }\end{array}$ & $\begin{array}{l}\text { Disrupt NOX enzyme } \\
\text { assembly }\end{array}$ & $\begin{array}{c}\text { Bind with NOX subunits } \\
\text { disrupting NOX } \\
\text { assembly }\end{array}$ & $\begin{array}{l}\text { Cell free and cell-based } \\
\text { assays }\end{array}$ & [289] \\
\hline GSK2795039 & $\begin{array}{l}\text { Compete for NADPH } \\
\text { binding site }\end{array}$ & $\begin{array}{c}\text { Specifically inhibit NOX2 } \\
\text { by excluding NADPH } \\
\text { binding }\end{array}$ & $\begin{array}{l}\text { Cell based, cell-free assays } \\
\text { and animal model of acute } \\
\text { pancreatitis }\end{array}$ & [277] \\
\hline Ebselen and analogue & $\begin{array}{c}\text { Blocks } \mathrm{p} 47^{\text {phox }} \text { cell } \\
\text { membrane migration and } \\
\text { NOX assembly }\end{array}$ & $\begin{array}{l}\text { Inhibits NOX1 and } \\
\text { NOX2 assembly }\end{array}$ & $\begin{array}{l}\text { Human neutrophil and } \\
\text { cell-free assays }\end{array}$ & [290] \\
\hline $\begin{array}{c}\text { GKT137831 } \\
\text { (Phase } 2 \text { clinical trials for } \\
\text { diabetic complications) }\end{array}$ & $\begin{array}{l}\text { Direct interaction with } \\
\text { NOX complex }\end{array}$ & Inhibits NOX1/4 activity & $\begin{array}{l}\text { Cell-free assays and } \\
\text { animal models }\end{array}$ & {$[268,291]$} \\
\hline $\begin{array}{c}\text { APX115 } \\
\text { (Phase } 1 \text { clinical trials) } \\
\text { (Phase } 2 \text { clinical trials for } \\
\text { Covid-19) }\end{array}$ & Unknown & $\begin{array}{l}\text { Decreases the expression } \\
\text { of NOX1-3 proteins }\end{array}$ & Diabetic mouse model & [278] \\
\hline $\begin{array}{c}\text { Aspirin } \\
\text { (FDA Approved drug) }\end{array}$ & Unknown & Lowers Nox 4 enzyme & Human endothelial cells & [292] \\
\hline
\end{tabular}

Note: the list if not exhaustive.

\section{Conclusions}

There is now a compelling body of evidence that ROS play an important secondary messenger role in the modulation of various oncogenic signalling pathways associated with the initiation and progression of different cancers, including ALL (Figure 1). There is also conclusive evidence that redox dysfunction plays an important role in the leukaemogenesis of ALL. Metabolic adaptation, mitochondrial transfer, hypoxia, activation/upregulation/ constitutive activation of oncogenic signalling pathways and dysregulation of cellular antioxidant systems all converge to drive a state of pro-oxidation, which propagates further insult to the genome and leads to clonal evolution, treatment resistance and poor outcomes. Capitalising on this knowledge, pro-oxidant therapies have had success in the treatment of ALL, however, this also leads to significant toxicity in healthy cells with potential shortand long-term complications. Therefore, an improved understanding of the sources and function of ROS in ALL is necessary to identify therapeutic modalities that selectively regulate the dynamic redox state of ALL to improve treatment and outcomes. In this context, a promising line of investigation is the application of antioxidant therapies, specifically 
those targeting the NOX family of enzymes, which represent an exciting drug target in ALL that has yet to be extensively explored.

Author Contributions: A.M. and M.D.D. conceived and designed the study; A.M., Z.P.G., J.R.S., J.C., B.N. and M.D.D. analysed the data. All authors wrote the manuscript. A.M. and M.D.D. designed the figures. All authors edited the manuscript and approved the final version. All authors have read and agreed to the published version of the manuscript.

Funding: M.D.D. is supported by an NHMRC Investigator Grant-GNT1173892. The contents of the published material are solely the responsibility of the research institutions involved or individual authors and do not reflect the views of NHMRC. M.D.D. is also supported by Defeat DIPG ChadTough New Investigator Fellowship. This project was supported by the Cancer Institute NSW, Jurox, Hunter Children's Research Foundation, Zebra Equities and The Hunter Medical Research Institute.

Institutional Review Board Statement: Not applicable.

Informed Consent Statement: Not applicable.

Data Availability Statement: Data is contained within the article.

Conflicts of Interest: The authors declare no conflict of interest.

$\begin{array}{ll}\text { Abbreviations } \\ \text { ALL } & \text { Acute lymphoblastic leukemia } \\ \text { AML } & \text { Acute myeloid leukemia } \\ \text { AP-1 } & \text { Activator protein 1 } \\ \text { Ara-C } & \text { Cytosine arabinoside } \\ \text { ARE } & \text { Antioxidant responsive elements } \\ \text { ATM } & \text { Ataxia-telangiectasia mutation } \\ \text { ATO } & \text { Arsenic trioxide } \\ \text { ATP } & \text { Guanosine diphosphate } \\ \text { BCR } & \text { B cell receptor } \\ \text { BCR-ABL } & \text { Breakpoint cluster-Abelson } \\ \text { CAT } & \text { Catalase } \\ \text { CDK } & \text { Cyclin dependent kinases } \\ \text { ClpP } & \text { caseinolytic protease P } \\ \text { CRLF2 } & \text { Cytokine receptor-like factor 2 } \\ \text { CREB } & \text { cAMP-responsive element binding } \\ \text { DPI } & \text { Diphenyleneiodonium } \\ \text { DS } & \text { Down syndrome } \\ \text { DSB } & \text { Double-strand break } \\ \text { DUOX } & \text { Dual oxidase } \\ \text { EPOR } & \text { Erythropoietin receptor } \\ \text { EPX } & \text { Eosinophil peroxidase } \\ \text { ETC } & \text { Electron transport chain } \\ \text { ETS } & \text { E26-transformation-specific (ETS) transcription factors } \\ \text { ETV } & \text { ETS variant transcription factor 6 } \\ \text { FLT3 } & \text { FMS-like tyrosine kinase 3 } \\ \text { FLT3-ITD } & \text { FLT3-internal tandem duplication } \\ \text { FoXO } & \text { Forkhead box class O } \\ \text { GPx } & \text { Glutathione peroxidase } \\ \text { GSH } & \text { Reduced glutathione } \\ \text { GSK-3 } & \text { Glycogen synthase kinase-3 } \\ \text { GSK-3 } & \text { Glycogen synthase kinase-3 } \\ \text { GSSG } & \text { Oxidized glutathione } \\ \text { GSR } & \text { GSSG reductase } \\ \text { GST } & \text { Glutathione S-transferases } \\ & \end{array}$




\begin{tabular}{|c|c|}
\hline GTP & Guanosine triphosphate \\
\hline HDAC & Histone deacetylase \\
\hline $\mathrm{H}_{2} \mathrm{O}_{2}$ & Hydrogen peroxide \\
\hline HIF & Hypoxia inducible factors \\
\hline $\mathrm{HO}-$ & Hydroxyl radical \\
\hline HRR & Homologous recombinational repair \\
\hline HSCs & Hematopoietic stem cells \\
\hline Ikzf3 & IKAROS family zinc finger 3 \\
\hline IL-2 & Interleukin-2 \\
\hline IL7R & Interleukin-7 receptor \\
\hline JAK & Janus Kinase \\
\hline Keap1 & Helch-like ECH-associated protein \\
\hline LICs & Leukaemic initiating cells \\
\hline LPO & Lactoperoxidase \\
\hline LPS & lipopolysaccharide \\
\hline LSCs & Leukemic stem cells \\
\hline MDV & Mitochondria-derived vesicle \\
\hline MLL & Mixed-lineage leukemia \\
\hline MnSOD & Manganese superoxide dismutase \\
\hline MPO & Myeloperoxidase \\
\hline mTOR & Mammalian target of rapamycin \\
\hline NAC & $\mathrm{N}$-acetyl-L-cysteine \\
\hline NFAT & Nuclear factor of activated T-cells \\
\hline NHEJ & Non-homologous end joining \\
\hline $\mathrm{NO}-$ & Nitric oxide \\
\hline NOTCH1 & Neurogenic locus notch homolog protein 1 \\
\hline NOX & Nicotinamide adenine dinucleotide phosphate oxidase \\
\hline NQO1 & NAD(P)H quinone oxidoreductase 1 \\
\hline Nrf2 & Nuclear factor (erythroid-derived)-like 2 \\
\hline $\mathrm{O}_{2}-$ & Superoxide anion \\
\hline $\mathrm{O}_{3}$ & Ozone \\
\hline OS & Overall survival \\
\hline $\mathrm{Ph}$ & Philadelphia chromosome \\
\hline PIKK & PI3K-like protein kinase \\
\hline PKC & Protein kinase $\mathrm{C}$ \\
\hline PRX & Peroxiredoxin \\
\hline PTEN & Phosphatase and tensin homolog \\
\hline PTMs & Post-translational modifications \\
\hline RASGRP1 & RAS guanine nucleotide-releasing protein 1 \\
\hline RAC & Ras-related C3 botulinum toxin substrate \\
\hline Rap1 & Ras-related protein 1 \\
\hline RASGRP & RAS guanyl nucleotide-releasing protein \\
\hline $\mathrm{Rb}$ & Retinoblastoma protein \\
\hline ROS & Reactive oxygen species \\
\hline RTK & Receptor tyrosin kinase \\
\hline RUNX1 & Runt-related transcription factor 1 \\
\hline SDH & Succinate dehydrogenase \\
\hline SOD & Superoxide dismutase \\
\hline STAT & Signal transducer and activator of transcription \\
\hline SYK & Spleen tyrosine kinase \\
\hline TBB & Tetrabromobenzotriazole \\
\hline TCR & $\mathrm{T}$ cell receptor \\
\hline TLR & Toll-like receptor \\
\hline TNTs & Tunnelling nanotubes \\
\hline TPGS & D- $\alpha$-tocopheryl polyethylene glycol 1000 succinate \\
\hline TRX & Thioredoxin \\
\hline TSC & Tuberous sclerosis complex \\
\hline TSLP & thymic stromal lymphopoietin \\
\hline TXNRD & Thioredoxin reductase \\
\hline
\end{tabular}




\section{References}

1. Terwilliger, T.; Abdul-Hay, M. Acute lymphoblastic leukemia: A comprehensive review and 2017 update. Blood Cancer J. 2017, 7, e577. [CrossRef]

2. Ward, E.; DeSantis, C.; Robbins, A.; Kohler, B.; Jemal, A. Childhood and adolescent cancer statistics, 2014. CA 2014, 64, 83-103. [CrossRef] [PubMed]

3. American Cancer Society. Key Statistics for Acute Lymphocytic Leukemia (ALL). Available online: https://www.cancer.org/ cancer/acute-lymphocytic-leukemia/about/key-statistics.html\#references (accessed on 12 October 2021).

4. Hunger, S.P.; Mullighan Charles, G. Acute Lymphoblastic Leukemia in Children. N. Engl. J. Med. 2015, 373, 1541-1552. [CrossRef] [PubMed]

5. Bostrom, B.C.; Sensel, M.R.; Sather, H.N.; Gaynon, P.S.; La, M.K.; Johnston, K.; Erdmann, G.R.; Gold, S.; Heerema, N.A.; Hutchinson, R.J.; et al. Dexamethasone versus prednisone and daily oral versus weekly intravenous mercaptopurine for patients with standard-risk acute lymphoblastic leukemia: A report from the Children's Cancer Group. Blood 2003, 101, $3809-3817$. [CrossRef] [PubMed]

6. Kidd, J.G. Regression of transplanted lymphomas induced in vivo by means of normal guinea pig serum. II. Studies on the nature of the active serum constituent: Histological mechanism of the regression: Tests for effects of guinea pig serum on lymphoma cells in vitro: Discussion. J. Exp. Med. 1953, 98, 583-606. [CrossRef]

7. Escherich, G.; Zimmermann, M.; Janka-Schaub, G.; CoALL Study Group. Doxorubicin or daunorubicin given upfront in a therapeutic window are equally effective in children with newly diagnosed acute lymphoblastic leukemia. A randomized comparison in trial CoALL 07-03. Pediatr. Blood Cancer 2013, 60, 254-257. [CrossRef]

8. Nguyen, K.; Devidas, M.; Cheng, S.C.; La, M.; Raetz, E.A.; Carroll, W.L.; Winick, N.J.; Hunger, S.P.; Gaynon, P.S.; Loh, M.L.; et al. Factors influencing survival after relapse from acute lymphoblastic leukemia: A Children's Oncology Group study. Leukemia 2008, 22, 2142-2150. [CrossRef]

9. Oriol, A.; Vives, S.; Hernández-Rivas, J.-M.; Tormo, M.; Heras, I.; Rivas, C.; Bethencourt, C.; Moscardó, F.; Bueno, J.; Grande, C.; et al. Outcome after relapse of acute lymphoblastic leukemia in adult patients included in four consecutive risk-adapted trials by the PETHEMA Study Group. Haematologica 2010, 95, 589-596. [CrossRef]

10. Board, P.P.T.E. PDQ Childhood Acute Lymphoblastic Leukemia Treatment. In Bethesda; National Cancer Institute: Bethesda, MD, USA, 2021.

11. Inaba, H.; Mullighan, C.G. Pediatric acute lymphoblastic leukemia. Haematologica 2020, 105, 2524-2539. [CrossRef] [PubMed]

12. Mullighan, C.G.; Miller, C.B.; Radtke, I.; Phillips, L.A.; Dalton, J.; Ma, J.; White, D.; Hughes, T.P.; Le Beau, M.M.; Pui, C.H.; et al. BCR-ABL1 lymphoblastic leukaemia is characterized by the deletion of Ikaros. Nature 2008, 453, 110-114. [CrossRef] [PubMed]

13. Kontro, M.; Kuusanmaki, H.; Eldfors, S.; Burmeister, T.; Andersson, E.I.; Bruserud, O.; Brummendorf, T.H.; Edgren, H.; Gjertsen, B.T.; Itala-Remes, M.; et al. Novel activating STAT5B mutations as putative drivers of T-cell acute lymphoblastic leukemia. Leukemia 2014, 28, 1738-1742. [CrossRef]

14. Holmfeldt, L.; Wei, L.; Diaz-Flores, E.; Walsh, M.; Zhang, J.; Ding, L.; Payne-Turner, D.; Churchman, M.; Andersson, A.; Chen, S.C.; et al. The genomic landscape of hypodiploid acute lymphoblastic leukemia. Nat. Genet. 2013, 45, 242-252. [CrossRef] [PubMed]

15. Liu, Y.; Easton, J.; Shao, Y.; Maciaszek, J.; Wang, Z.; Wilkinson, M.R.; McCastlain, K.; Edmonson, M.; Pounds, S.B.; Shi, L.; et al. The genomic landscape of pediatric and young adult T-lineage acute lymphoblastic leukemia. Nat. Genet. 2017, 49, 1211-1218. [CrossRef] [PubMed]

16. Weng, A.P.; Ferrando, A.A.; Lee, W.; Morris, J.P.t.; Silverman, L.B.; Sanchez-Irizarry, C.; Blacklow, S.C.; Look, A.T.; Aster, J.C. Activating mutations of NOTCH1 in human T cell acute lymphoblastic leukemia. Science 2004, 306, 269-271. [CrossRef]

17. Palomero, T.; Sulis, M.L.; Cortina, M.; Real, P.J.; Barnes, K.; Ciofani, M.; Caparros, E.; Buteau, J.; Brown, K.; Perkins, S.L.; et al. Mutational loss of PTEN induces resistance to NOTCH1 inhibition in T-cell leukemia. Nat. Med. 2007, 13, 1203-1210. [CrossRef] [PubMed]

18. Kharas, M.G.; Janes, M.R.; Scarfone, V.M.; Lilly, M.B.; Knight, Z.A.; Shokat, K.M.; Fruman, D.A. Ablation of PI3K blocks BCR-ABL leukemogenesis in mice, and a dual PI3K/mTOR inhibitor prevents expansion of human BCR-ABL+ leukemia cells. J. Clin. Investig. 2008, 118, 3038-3050. [CrossRef]

19. Yamamoto, T.; Isomura, M.; Xu, Y.; Liang, J.; Yagasaki, H.; Kamachi, Y.; Kudo, K.; Kiyoi, H.; Naoe, T.; Kojma, S. PTPN11, RAS and FLT3 mutations in childhood acute lymphoblastic leukemia. Leuk. Res. 2006, 30, 1085-1089. [CrossRef]

20. Armstrong, S.A.; Mabon, M.E.; Silverman, L.B.; Li, A.; Gribben, J.G.; Fox, E.A.; Sallan, S.E.; Korsmeyer, S.J. FLT3 mutations in childhood acute lymphoblastic leukemia. Blood 2004, 103, 3544-3546. [CrossRef]

21. Degryse, S.; de Bock, C.E.; Demeyer, S.; Govaerts, I.; Bornschein, S.; Verbeke, D.; Jacobs, K.; Binos, S.; Skerrett-Byrne, D.A.; Murray, H.C.; et al. Mutant JAK3 phosphoproteomic profiling predicts synergism between JAK3 inhibitors and MEK/BCL2 inhibitors for the treatment of T-cell acute lymphoblastic leukemia. Leukemia 2018, 32, 788-800. [CrossRef]

22. Den Boer, M.L.; van Slegtenhorst, M.; De Menezes, R.X.; Cheok, M.H.; Buijs-Gladdines, J.G.; Peters, S.T.; Van Zutven, L.J.; Beverloo, H.B.; Van der Spek, P.J.; Escherich, G.; et al. A subtype of childhood acute lymphoblastic leukaemia with poor treatment outcome: A genome-wide classification study. Lancet Oncol. 2009, 10, 125-134. [CrossRef] 
23. Paulsson, K.; Lilljebjorn, H.; Biloglav, A.; Olsson, L.; Rissler, M.; Castor, A.; Barbany, G.; Fogelstrand, L.; Nordgren, A.; Sjogren, H.; et al. The genomic landscape of high hyperdiploid childhood acute lymphoblastic leukemia. Nat. Genet. 2015, 47, 672-676. [CrossRef]

24. Neri, A.; Knowles, D.M.; Greco, A.; McCormick, F.; Dalla-Favera, R. Analysis of RAS oncogene mutations in human lymphoid malignancies. Proc. Natl. Acad. Sci. USA 1988, 85, 9268-9272. [CrossRef]

25. Sillar, J.R.; Germon, Z.P.; Deluliis, G.N.; Dun, M.D. The Role of Reactive Oxygen Species in Acute Myeloid Leukaemia. Int. J. Mol. Sci. 2019, 20, 6003. [CrossRef]

26. Phaniendra, A.; Jestadi, D.B.; Periyasamy, L. Free radicals: Properties, sources, targets, and their implication in various diseases. Indian J. Clin. Biochem. 2015, 30, 11-26. [CrossRef] [PubMed]

27. Aggarwal, V.; Tuli, H.S.; Varol, A.; Thakral, F.; Yerer, M.B.; Sak, K.; Varol, M.; Jain, A.; Khan, M.A.; Sethi, G. Role of Reactive Oxygen Species in Cancer Progression: Molecular Mechanisms and Recent Advancements. Biomolecules 2019, 9, 735. [CrossRef] [PubMed]

28. Hole, P.S.; Pearn, L.; Tonks, A.J.; James, P.E.; Burnett, A.K.; Darley, R.L.; Tonks, A. Ras-induced reactive oxygen species promote growth factor-independent proliferation in human CD34+ hematopoietic progenitor cells. Blood 2010, 115, 1238-1246. [CrossRef] [PubMed]

29. Srinivas, U.S.; Tan, B.W.Q.; Vellayappan, B.A.; Jeyasekharan, A.D. ROS and the DNA damage response in cancer. Redox Biol. 2019, 25, 101084. [CrossRef]

30. Sallmyr, A.; Fan, J.; Rassool, F.V. Genomic instability in myeloid malignancies: Increased reactive oxygen species (ROS), DNA double strand breaks (DSBs) and error-prone repair. Cancer Lett. 2008, 270, 1-9. [CrossRef]

31. Barrera, G. Oxidative stress and lipid peroxidation products in cancer progression and therapy. ISRN Oncol. 2012, $2012,137289$. [CrossRef]

32. Adane, B.; Ye, H.; Khan, N.; Pei, S.; Minhajuddin, M.; Stevens, B.M.; Jones, C.L.; D'Alessandro, A.; Reisz, J.A.; Zaberezhnyy, V.; et al. The Hematopoietic Oxidase NOX2 Regulates Self-Renewal of Leukemic Stem Cells. Cell Rep. 2019, 27, 238-254. [CrossRef]

33. Maraldi, T.; Angeloni, C.; Prata, C.; Hrelia, S. NADPH Oxidases: Redox Regulators of Stem Cell Fate and Function. Antioxidants 2021, 10, 973. [CrossRef]

34. Chen, C.; Hao, X.; Lai, X.; Liu, L.; Zhu, J.; Shao, H.; Huang, D.; Gu, H.; Zhang, T.; Yu, Z.; et al. Oxidative phosphorylation enhances the leukemogenic capacity and resistance to chemotherapy of B cell acute lymphoblastic leukemia. Sci. Adv. 2021, 7, eabd6280. [CrossRef]

35. Chen, Y.; Liang, Y.; Luo, X.; Hu, Q. Oxidative resistance of leukemic stem cells and oxidative damage to hematopoietic stem cells under pro-oxidative therapy. Cell Death Dis. 2020, 11, 291. [CrossRef]

36. Liu, L.; Zhang, K.; Sandoval, H.; Yamamoto, S.; Jaiswal, M.; Sanz, E.; Li, Z.; Hui, J.; Graham, B.H.; Quintana, A.; et al. Glial lipid droplets and ROS induced by mitochondrial defects promote neurodegeneration. Cell 2015, 160, 177-190. [CrossRef]

37. Cafe, S.L.; Nixon, B.; Dun, M.D.; Roman, S.D.; Bernstein, I.R.; Bromfield, E.G. Oxidative Stress Dysregulates Protein Homeostasis Within the Male Germ Line. Antioxid. Redox Signal. 2020, 32, 487-503. [CrossRef]

38. Liguori, I.; Russo, G.; Curcio, F.; Bulli, G.; Aran, L.; Della-Morte, D.; Gargiulo, G.; Testa, G.; Cacciatore, F.; Bonaduce, D.; et al. Oxidative stress, aging, and diseases. Clin. Interv. Aging 2018, 13, 757-772. [CrossRef] [PubMed]

39. Volpe, C.M.O.; Villar-Delfino, P.H.; Dos Anjos, P.M.F.; Nogueira-Machado, J.A. Cellular death, reactive oxygen species (ROS) and diabetic complications. Cell. Death Dis. 2018, 9, 119. [CrossRef] [PubMed]

40. Nunes, P.; Demaurex, N.; Dinauer, M.C. Regulation of the NADPH Oxidase and Associated Ion Fluxes During Phagocytosis. Traffic 2013, 14, 1118-1131. [CrossRef] [PubMed]

41. Dahlgren, C.; Karlsson, A. Respiratory burst in human neutrophils. J. Immunol. Methods 1999, 232, 3-14. [CrossRef]

42. Ruhnau, J.; Schulze, K.; Gaida, B.; Langner, S.; Kessler, C.; Bröker, B.; Dressel, A.; Vogelgesang, A. Stroke Alters Respiratory Burst in Neutrophils and Monocytes. Stroke 2014, 45, 794-800. [CrossRef]

43. Iles, K.E.; Forman, H.J. Macrophage signaling and respiratory burst. Immunol. Res. 2002, 26, 95-105. [CrossRef]

44. Panday, A.; Sahoo, M.K.; Osorio, D.; Batra, S. NADPH oxidases: An overview from structure to innate immunity-associated pathologies. Cell. Mol. Immunol. 2015, 12, 5-23. [CrossRef]

45. Valente, A.J.; Zhou, Q.; Lu, Z.; He, W.; Qiang, M.; Ma, W.; Li, G.; Wang, L.; Banfi, B.; Steger, K.; et al. Regulation of NOX1 expression by GATA, HNF-1 $\alpha$, and Cdx transcription factors. Free. Radic. Biol. Med. 2008, 44, 430-443. [CrossRef] [PubMed]

46. Arakawa, N.; Katsuyama, M.; Matsuno, K.; Urao, N.; Tabuchi, Y.; Okigaki, M.; Matsubara, H.; Yabe-Nishimura, C. Novel transcripts of Nox1 are regulated by alternative promoters and expressed under phenotypic modulation of vascular smooth muscle cells. Biochem. J. 2006, 398, 303-310. [CrossRef] [PubMed]

47. Wang, D.; Youngson, C.; Wong, V.; Yeger, H.; Dinauer, M.C.; de Miera, E.V.-S.; Rudy, B.; Cutz, E. NADPH-oxidase and a hydrogen peroxide-sensitive $\mathrm{K}^{+}$channel may function as an oxygen sensor complex in airway chemoreceptors and small cell lung carcinoma cell lines. Proc. Natl. Acad. Sci. USA 1996, 93, 13182-13187. [CrossRef] [PubMed]

48. Jones, S.A.; Hancock, J.T.; Jones, O.T.; Neubauer, A.; Topley, N. The expression of NADPH oxidase components in human glomerular mesangial cells: Detection of protein and mRNA for p47phox, p67phox, and p22phox. J. Am. Soc. Nephrol. 1995, 5, 1483-1491. [CrossRef] [PubMed]

49. Cheng, G.; Cao, Z.; Xu, X.; Meir, E.G.V.; Lambeth, J.D. Homologs of gp91phox: Cloning and tissue expression of Nox3, Nox4, and Nox5. Gene 2001, 269, 131-140. [CrossRef] 
50. Jones, S.A.; O’Donnell, V.B.; Wood, J.D.; Broughton, J.P.; Hughes, E.J.; Jones, O.T. Expression of phagocyte NADPH oxidase components in human endothelial cells. Am. J. Physiol.-Heart Circ. Physiol. 1996, 271, H1626-H1634. [CrossRef]

51. Bánfi, B.; Molnár, G.; Maturana, A.; Steger, K.; Hegedûs, B.; Demaurex, N.; Krause, K.-H. A Ca ${ }^{2+}$-activated NADPH Oxidase in Testis, Spleen, and Lymph Nodes *. J. Biol. Chem. 2001, 276, 37594-37601. [CrossRef]

52. Koschmann, C.; Farooqui, Z.; Kasaian, K.; Cao, X.; Zamler, D.; Stallard, S.; Venneti, S.; Hervey-Jumper, S.; Garton, H.; Muraszko, K.; et al. Multi-focal sequencing of a diffuse intrinsic pontine glioma establishes PTEN loss as an early event. npj Precision Oncology 2017, 1, 32. [CrossRef]

53. Finelli, M.J. Redox Post-translational Modifications of Protein Thiols in Brain Aging and Neurodegenerative Conditions-Focus on S-Nitrosation. Front. Aging Neurosci. 2020, 12, 254. [CrossRef] [PubMed]

54. Chouchani, E.T.; Kazak, L.; Spiegelman, B.M. Mitochondrial reactive oxygen species and adipose tissue thermogenesis: Bridging physiology and mechanisms. J. Biol. Chem. 2017, 292, 16810-16816. [CrossRef] [PubMed]

55. St-Pierre, J.; Buckingham, J.A.; Roebuck, S.J.; Brand, M.D. Topology of Superoxide Production from Different Sites in the Mitochondrial Electron Transport Chain *. J. Biol. Chem. 2002, 277, 44784-44790. [CrossRef] [PubMed]

56. Turrens, J.F. Mitochondrial formation of reactive oxygen species. J. Physiol. 2003, 552, 335-344. [CrossRef]

57. Magder, S. Reactive oxygen species: Toxic molecules or spark of life? Crit. Care 2006, 10, 208. [CrossRef] [PubMed]

58. Sies, H. Hydrogen peroxide as a central redox signaling molecule in physiological oxidative stress: Oxidative eustress. Redox Biol. 2017, 11, 613-619. [CrossRef] [PubMed]

59. Winterbourn, C.C. Toxicity of iron and hydrogen peroxide: The Fenton reaction. Toxicol. Lett. 1995, 82-83, 969-974. [CrossRef]

60. Chen, Y.; Li, J.; Zhao, Z. Redox Control in Acute Lymphoblastic Leukemia: From Physiology to Pathology and Therapeutic Opportunities. Cells 2021, 10, 1218. [CrossRef]

61. Birben, E.; Sahiner, U.M.; Sackesen, C.; Erzurum, S.; Kalayci, O. Oxidative stress and antioxidant defense. World Allergy Organ J. 2012, 5, 9-19. [CrossRef]

62. Chen, L.; Li, X.; Zhang, J.; Fang, J.; Huang, Y.; Wang, P.; Ma, J. Production of Hydroxyl Radical via the Activation of Hydrogen Peroxide by Hydroxylamine. Environ. Sci. Technol. 2015, 49, 10373-10379. [CrossRef] [PubMed]

63. Murley, J.S.; Kataoka, Y.; Miller, R.C.; Li, J.J.; Woloschak, G.; Grdina, D.J. SOD2-Mediated Effects Induced by WR1065 and Low-Dose Ionizing Radiation on Micronucleus Formation in RKO Human Colon Carcinoma Cells. Radiat. Res. 2010, 175, 57-65. [CrossRef] [PubMed]

64. Melov, S.; Coskun, P.; Patel, M.; Tuinstra, R.; Cottrell, B.; Jun, A.S.; Zastawny, T.H.; Dizdaroglu, M.; Goodman, S.I.; Huang, T.-T.; et al. Mitochondrial disease in superoxide dismutase 2 mutant mice. Proc. Natl. Acad. Sci. USA 1999, 96, 846-851. [CrossRef] [PubMed]

65. Fitzmaurice, C.; Allen, C.; Barber, R.M.; Barregard, L.; Bhutta, Z.A.; Brenner, H.; Dicker, D.J.; Chimed-Orchir, O.; Dandona, R.; Dandona, L.; et al. Global, Regional, and National Cancer Incidence, Mortality, Years of Life Lost, Years Lived With Disability, and Disability-Adjusted Life-years for 32 Cancer Groups, 1990 to 2015: A Systematic Analysis for the Global Burden of Disease Study. JAMA Oncol. 2017, 3, 524-548. [CrossRef] [PubMed]

66. Shao, L.; Li, H.; Pazhanisamy, S.K.; Meng, A.; Wang, Y.; Zhou, D. Reactive oxygen species and hematopoietic stem cell senescence. Int. J. Hematol. 2011, 94, 24-32. [CrossRef]

67. Eliasson, P.; Rehn, M.; Hammar, P.; Larsson, P.; Sirenko, O.; Flippin, L.A.; Cammenga, J.; Jönsson, J.-I. Hypoxia mediates low cell-cycle activity and increases the proportion of long-term-reconstituting hematopoietic stem cells during in vitro culture. Exp. Hematol. 2010, 38, 301-310. [CrossRef]

68. Takubo, K.; Goda, N.; Yamada, W.; Iriuchishima, H.; Ikeda, E.; Kubota, Y.; Shima, H.; Johnson, R.S.; Hirao, A.; Suematsu, M.; et al. Regulation of the HIF-1 $\alpha$ Level Is Essential for Hematopoietic Stem Cells. Cell Stem. Cell 2010, 7, 391-402. [CrossRef] [PubMed]

69. Rouault-Pierre, K.; Lopez-Onieva, L.; Foster, K.; Anjos-Afonso, F.; Lamrissi-Garcia, I.; Serrano-Sanchez, M.; Mitter, R.; Ivanovic, Z.; deVerneuil, H.; Gribben, J.; et al. HIF-2 $\alpha$; Protects Human Hematopoietic Stem/Progenitors and Acute Myeloid Leukemic Cells from Apoptosis Induced by Endoplasmic Reticulum Stress. Cell Stem. Cell 2013, 13, 549-563. [CrossRef]

70. Miyamoto, K.; Araki, K.Y.; Naka, K.; Arai, F.; Takubo, K.; Yamazaki, S.; Matsuoka, S.; Miyamoto, T.; Ito, K.; Ohmura, M.; et al. Foxo3a Is Essential for Maintenance of the Hematopoietic Stem Cell Pool. Cell Stem. Cell 2007, 1, 101-112. [CrossRef]

71. Tothova, Z.; Kollipara, R.; Huntly, B.J.; Lee, B.H.; Castrillon, D.H.; Cullen, D.E.; McDowell, E.P.; Lazo-Kallanian, S.; Williams, I.R.; Sears, C.; et al. FoxOs Are Critical Mediators of Hematopoietic Stem Cell Resistance to Physiologic Oxidative Stress. Cell 2007, 128, 325-339. [CrossRef]

72. Duchatel, R.J.; Jackson, E.R.; Alvaro, F.; Nixon, B.; Hondermarck, H.; Dun, M.D. Signal Transduction in Diffuse Intrinsic Pontine Glioma. Proteomics 2019, 19, e1800479. [CrossRef]

73. Koundouros, N.; Poulogiannis, G. Phosphoinositide 3-Kinase/Akt Signaling and Redox Metabolism in Cancer. Front. Oncol. 2018, 8, 160. [CrossRef]

74. Chen, Q.; Powell, D.W.; Rane, M.J.; Singh, S.; Butt, W.; Klein, J.B.; McLeish, K.R. Akt Phosphorylates p47 ${ }^{\text {phox }}$ and Mediates Respiratory Burst Activity in Human Neutrophils. J. Immunol. 2003, 170, 5302-5308. [CrossRef] [PubMed]

75. Zhang, J.; Grindley, J.C.; Yin, T.; Jayasinghe, S.; He, X.C.; Ross, J.T.; Haug, J.S.; Rupp, D.; Porter-Westpfahl, K.S.; Wiedemann, L.M.; et al. PTEN maintains haematopoietic stem cells and acts in lineage choice and leukaemia prevention. Nature 2006, 441, 518-522. [CrossRef] 
76. Kharas, M.G.; Okabe, R.; Ganis, J.J.; Gozo, M.; Khandan, T.; Paktinat, M.; Gilliland, D.G.; Gritsman, K. Constitutively active AKT depletes hematopoietic stem cells and induces leukemia in mice. Blood 2010, 115, 1406-1415. [CrossRef] [PubMed]

77. Juntilla, M.M.; Patil, V.D.; Calamito, M.; Joshi, R.P.; Birnbaum, M.J.; Koretzky, G.A. AKT1 and AKT2 maintain hematopoietic stem cell function by regulating reactive oxygen species. Blood 2010, 115, 4030-4038. [CrossRef]

78. Chen, C.; Liu, Y.; Liu, R.; Ikenoue, T.; Guan, K.-L.; Liu, Y.; Zheng, P. TSC-mTOR maintains quiescence and function of hematopoietic stem cells by repressing mitochondrial biogenesis and reactive oxygen species. J. Exp. Med. 2008, 205, 2397-2408. [CrossRef]

79. Ito, K.; Hirao, A.; Arai, F.; Matsuoka, S.; Mak, T.W.; Suda, T. Regulation of Oxidative Stress by ATM Is Required for the Self-Renewal of Haematopoietic Stem Cells. Blood 2004, 104, 369. [CrossRef]

80. Cosentino, C.; Grieco, D.; Costanzo, V. ATM activates the pentose phosphate pathway promoting anti-oxidant defence and DNA repair. EMBO J. 2011, 30, 546-555. [CrossRef] [PubMed]

81. Fasouli, E.S.; Katsantoni, E. JAK-STAT in Early Hematopoiesis and Leukemia. Front. Cell Dev. Biol. 2021, 9, 669363. [CrossRef] [PubMed]

82. Akada, H.; Akada, S.; Hutchison, R.E.; Sakamoto, K.; Wagner, K.-U.; Mohi, G. Critical Role of Jak2 in the Maintenance and Function of Adult Hematopoietic Stem Cells. Stem. Cells 2014, 32, 1878-1889. [CrossRef]

83. Jayavelu, A.K.; Müller, J.P.; Bauer, R.; Böhmer, S.A.; Lässig, J.; Cerny-Reiterer, S.; Sperr, W.R.; Valent, P.; Maurer, B.; Moriggl, R.; et al. NOX4-driven ROS formation mediates PTP inactivation and cell transformation in FLT3ITD-positive AML cells. Leukemia 2016, 30, 473-483. [CrossRef]

84. Vilas-Zornoza, A.; Agirre, X.; Martin-Palanco, V.; Martin-Subero, J.I.; San Jose-Eneriz, E.; Garate, L.; Alvarez, S.; Miranda, E.; Rodriguez-Otero, P.; Rifon, J.; et al. Frequent and simultaneous epigenetic inactivation of TP53 pathway genes in acute lymphoblastic leukemia. PLOS ONE 2011, 6, e17012. [CrossRef] [PubMed]

85. Cho, H.J.; Lee, J.; Yoon, S.R.; Lee, H.G.; Jung, H. Regulation of Hematopoietic Stem Cell Fate and Malignancy. Int. J. Mol. Sci. 2020, 21, 4780. [CrossRef]

86. Nathan, C.; Cunningham-Bussel, A. Beyond oxidative stress: An immunologist's guide to reactive oxygen species. Nat. Rev. Immunol. 2013, 13, 349-361. [CrossRef] [PubMed]

87. Roos, D. Chronic granulomatous disease. Br. Med. Bull. 2016, 118, 50-63. [CrossRef]

88. Arsenijevic, D.; Onuma, H.; Pecqueur, C.; Raimbault, S.; Manning, B.S.; Miroux, B.; Couplan, E.; Alves-Guerra, M.-C.; Goubern, M.; Surwit, R.; et al. Disruption of the uncoupling protein-2 gene in mice reveals a role in immunity and reactive oxygen species production. Nat. Genet. 2000, 26, 435-439. [CrossRef]

89. West, A.P.; Brodsky, I.E.; Rahner, C.; Woo, D.K.; Erdjument-Bromage, H.; Tempst, P.; Walsh, M.C.; Choi, Y.; Shadel, G.S.; Ghosh, S. TLR signalling augments macrophage bactericidal activity through mitochondrial ROS. Nature 2011, 472, 476-480. [CrossRef]

90. Abuaita, B.H.; Schultz, T.L.; O'Riordan, M.X. Mitochondria-Derived Vesicles Deliver Antimicrobial Reactive Oxygen Species to Control Phagosome-Localized Staphylococcus aureus. Cell Host Microbe 2018, 24, 625-636.e625. [CrossRef] [PubMed]

91. Zhang, H.; Wang, L.; Chu, Y. Reactive oxygen species: The signal regulator of B cell. Free Radic. Biol. Med. 2019, 142, 16-22. [CrossRef] [PubMed]

92. Sena, L.A.; Li, S.; Jairaman, A.; Prakriya, M.; Ezponda, T.; Hildeman, D.A.; Wang, C.-R.; Schumacker, P.T.; Licht, J.D.; Perlman, H.; et al. Mitochondria Are Required for Antigen-Specific T Cell Activation through Reactive Oxygen Species Signaling. Immunity 2013, 38, 225-236. [CrossRef]

93. Maly, F.E.; Cross, A.R.; Jones, O.T.; Wolf-Vorbeck, G.; Walker, C.; Dahinden, C.A.; De Weck, A.L. The superoxide generating system of B cell lines. Structural homology with the phagocytic oxidase and triggering via surface Ig. J. Immunol. 1988, 140, 2334-2339. [PubMed]

94. Maly, F.E.; Nakamura, M.; Gauchat, J.F.; Urwyler, A.; Walker, C.; Dahinden, C.A.; Cross, A.R.; Jones, O.T.; de Weck, A.L. Superoxide-dependent nitroblue tetrazolium reduction and expression of cytochrome b-245 components by human tonsillar B lymphocytes and B cell lines. J. Immunol. 1989, 142, 1260-1267.

95. Devadas, S.; Zaritskaya, L.; Rhee, S.G.; Oberley, L.; Williams, M.S. Discrete Generation of Superoxide and Hydrogen Peroxide by T Cell Receptor Stimulation: Selective Regulation of Mitogen-Activated Protein Kinase Activation and Fas Ligand Expression. J. Exp. Med. 2002, 195, 59-70. [CrossRef] [PubMed]

96. Zhang, J.H.; Ferrante, A.; Arrigo, A.P.; Dayer, J.M. Neutrophil stimulation and priming by direct contact with activated human T lymphocytes. J. Immunol. 1992, 148, 177-181.

97. Kwon, J.; Shatynski, K.E.; Chen, H.; Morand, S.; de Deken, X.; Miot, F.; Leto, T.L.; Williams, M.S. The nonphagocytic NADPH oxidase Duox1 mediates a positive feedback loop during T cell receptor signaling. Sci. Signal. 2010, 3, ra59. [CrossRef]

98. Franchina, D.G.; Dostert, C.; Brenner, D. Reactive Oxygen Species: Involvement in T Cell Signaling and Metabolism. Trends Immunol. 2018, 39, 489-502. [CrossRef] [PubMed]

99. Los, M.; Schenk, H.; Hexel, K.; Baeuerle, P.A.; Droge, W.; Schulze-Osthoff, K. IL-2 gene expression and NF-kappa B activation through CD28 requires reactive oxygen production by 5-lipoxygenase. EMBO J. 1995, 14, 3731-3740. [CrossRef]

100. Rolli, V.; Gallwitz, M.; Wossning, T.; Flemming, A.; Schamel, W.W.A.; Zürn, C.; Reth, M. Amplification of B Cell Antigen Receptor Signaling by a Syk/ITAM Positive Feedback Loop. Mol. Cell 2002, 10, 1057-1069. [CrossRef]

101. Wheeler, M.L.; Defranco, A.L. Prolonged production of reactive oxygen species in response to B cell receptor stimulation promotes B cell activation and proliferation. J. Immunol. 2012, 189, 4405-4416. [CrossRef] [PubMed] 
102. Nutt, S.L.; Urbánek, P.; Rolink, A.; Busslinger, M. Essential functions of Pax5 (BSAP) in pro-B cell development: Difference between fetal and adult B lymphopoiesis and reduced V-to-DJ recombination at the IgH locus. Genes Dev. 1997, 11, 476-491. [CrossRef] [PubMed]

103. Gu, Z.; Churchman, M.L.; Roberts, K.G.; Moore, I.; Zhou, X.; Nakitandwe, J.; Hagiwara, K.; Pelletier, S.; Gingras, S.; Berns, H.; et al. PAX5-driven subtypes of B-progenitor acute lymphoblastic leukemia. Nat. Genet. 2019, 51, 296-307. [CrossRef] [PubMed]

104. Alvarez, Y.; Coll, M.D.; Ortega, J.J.; Bastida, P.; Dastugue, N.; Robert, A.; Cervera, J.; Verdeguer, A.; Tasso, M.; Aventin, A.; et al. Genetic abnormalities associated with the $\mathrm{t}(12 ; 21)$ and their impact in the outcome of 56 patients with B-precursor acute lymphoblastic leukemia. Cancer Genet. Cytogenet. 2005, 162, 21-29. [CrossRef] [PubMed]

105. Sood, R.; Kamikubo, Y.; Liu, P. Role of RUNX1 in hematological malignancies. Blood 2017, 129, 2070-2082. [CrossRef] [PubMed]

106. Wray, J.P.; Deltcheva, E.M.; Boiers, C.; Richardson, S.E.; Chettri, J.B.; Gagrica, S.; Guo, Y.; Illendula, A.; Martens, J.H.A.; Stunnenberg, H.G.; et al. Cell cycle corruption in a preleukemic ETV6-RUNX1 model exposes RUNX1 addiction as a therapeutic target in acute lymphoblastic leukemia. bioRxiv 2020. [CrossRef]

107. Kantner, H.-P.; Warsch, W.; Delogu, A.; Bauer, E.; Esterbauer, H.; Casanova, E.; Sexl, V.; Stoiber, D. ETV6/RUNX1 Induces Reactive Oxygen Species and Drives the Accumulation of DNA Damage in B Cells. Neoplasia 2013, 15, 1292-IN1228. [CrossRef]

108. Schröder, K.; Kohnen, A.; Aicher, A.; Liehn, E.A.; Büchse, T.; Stein, S.; Weber, C.; Dimmeler, S.; Brandes, R.P. NADPH Oxidase Nox2 Is Required for Hypoxia-Induced Mobilization of Endothelial Progenitor Cells. Circ. Res. 2009, 105, 537-544. [CrossRef]

109. Teachey, D.T.; Pui, C.-H. Comparative features and outcomes between paediatric T-cell and B-cell acute lymphoblastic leukaemia. Lancet Oncol. 2019, 20, e142-e154. [CrossRef]

110. Kuan, J.W.; Su, A.T.; Leong, C.F.; Osato, M.; Sashida, G. Systematic Review of Normal Subjects Harbouring BCR-ABL1 Fusion Gene. Acta Haematol. 2020, 143, 96-111. [CrossRef]

111. Cilloni, D.; Saglio, G. Molecular Pathways: BCR-ABL. Clin. Cancer Res. 2012, 18, 930. [CrossRef]

112. Sattler, M.; Verma, S.; Shrikhande, G.; Byrne, C.H.; Pride, Y.B.; Winkler, T.; Greenfield, E.A.; Salgia, R.; Griffin, J.D. The BCR/ABL Tyrosine Kinase Induces Production of Reactive Oxygen Species in Hematopoietic Cells*. J. Biol. Chem. 2000, 275, 24273-24278. [CrossRef]

113. Koptyra, M.; Falinski, R.; Nowicki, M.O.; Stoklosa, T.; Majsterek, I.; Nieborowska-Skorska, M.; Blasiak, J.; Skorski, T. BCR/ABL kinase induces self-mutagenesis via reactive oxygen species to encode imatinib resistance. Blood 2006, 108, 319-327. [CrossRef]

114. Naughton, R.; Quiney, C.; Turner, S.D.; Cotter, T.G. Bcr-Abl-mediated redox regulation of the PI3K/AKT pathway. Leukemia 2009, 23, 1432-1440. [CrossRef]

115. Landry, W.D.; Woolley, J.F.; Cotter, T.G. Imatinib and Nilotinib inhibit Bcr-Abl-induced ROS through targeted degradation of the NADPH oxidase subunit p22phox. Leuk. Res. 2013, 37, 183-189. [CrossRef]

116. Cho, Y.J.; Zhang, B.; Kaartinen, V.; Haataja, L.; Curtis, I.d.; Groffen, J.; Heisterkamp, N. Generation of rac3 Null Mutant Mice: Role of Rac3 in Bcr/Abl-Caused Lymphoblastic Leukemia. Mol. Cell. Biol. 2005, 25, 5777-5785. [CrossRef]

117. Miyano, K.; Koga, H.; Minakami, R.; Sumimoto, H. The insert region of the Rac GTPases is dispensable for activation of superoxide-producing NADPH oxidases. Biochem. J. 2009, 422, 373-382. [CrossRef]

118. Koptyra, M.; Cramer, K.; Slupianek, A.; Richardson, C.; Skorski, T. BCR/ABL promotes accumulation of chromosomal aberrations induced by oxidative and genotoxic stress. Leukemia 2008, 22, 1969-1972. [CrossRef]

119. Deutsch, E.; Dugray, A.; AbdulKarim, B.; Marangoni, E.; Maggiorella, L.; Vaganay, S.; M’Kacher, R.; Rasy, S.D.; Eschwege, F.O.; Vainchenker, W.; et al. BCR-ABL down-regulates the DNA repair protein DNA-PKcs. Blood 2001, 97, 2084-2090. [CrossRef] [PubMed]

120. Slupianek, A.; Nowicki, M.O.; Koptyra, M.; Skorski, T. BCR/ABL modifies the kinetics and fidelity of DNA double-strand breaks repair in hematopoietic cells. DNA Repair 2006, 5, 243-250. [CrossRef] [PubMed]

121. Slupianek, A.; Schmutte, C.; Tombline, G.; Nieborowska-Skorska, M.; Hoser, G.; Nowicki, M.O.; Pierce, A.J.; Fishel, R.; Skorski, T. BCR/ABL Regulates Mammalian RecA Homologs, Resulting in Drug Resistance. Mol. Cell 2001, 8, 795-806. [CrossRef]

122. Staudt, D.; Murray, H.C.; McLachlan, T.; Alvaro, F.; Enjeti, A.K.; Verrills, N.M.; Dun, M.D. Targeting Oncogenic Signaling in Mutant FLT3 Acute Myeloid Leukemia: The Path to Least Resistance. Int. J. Mol. Sci. 2018, 19, 3198. [CrossRef] [PubMed]

123. Murray, H.C.; Enjeti, A.K.; Kahl, R.G.S.; Flanagan, H.M.; Sillar, J.; Skerrett-Byrne, D.A.; Al Mazi, J.G.; Au, G.G.; de Bock, C.E.; Evans, K.; et al. Quantitative phosphoproteomics uncovers synergy between DNA-PK and FLT3 inhibitors in acute myeloid leukaemia. Leukemia 2021, 35, 1782-1787. [CrossRef]

124. Al-Shami, A.; Spolski, R.; Kelly, J.; Fry, T.; Schwartzberg, P.L.; Pandey, A.; Mackall, C.L.; Leonard, W.J. A role for thymic stromal lymphopoietin in CD4(+) T cell development. J. Exp. Med. 2004, 200, 159-168. [CrossRef]

125. Russell, L.J.; Capasso, M.; Vater, I.; Akasaka, T.; Bernard, O.A.; Calasanz, M.J.; Chandrasekaran, T.; Chapiro, E.; Gesk, S.; Griffiths, M.; et al. Deregulated expression of cytokine receptor gene, CRLF2, is involved in lymphoid transformation in B-cell precursor acute lymphoblastic leukemia. Blood 2009, 114, 2688-2698. [CrossRef]

126. Jain, N.; Roberts, K.G.; Jabbour, E.; Patel, K.; Eterovic, A.K.; Chen, K.; Zweidler-McKay, P.; Lu, X.; Fawcett, G.; Wang, S.A.; et al. Ph-like acute lymphoblastic leukemia: A high-risk subtype in adults. Blood 2017, 129, 572-581. [CrossRef] [PubMed]

127. Roberts, K.G.; Pei, D.; Campana, D.; Payne-Turner, D.; Li, Y.; Cheng, C.; Sandlund, J.T.; Jeha, S.; Easton, J.; Becksfort, J.; et al. Outcomes of children with BCR-ABL1-like acute lymphoblastic leukemia treated with risk-directed therapy based on the levels of minimal residual disease. J. Clin. Oncol. 2014, 32, 3012-3020. [CrossRef] 
128. Tasian, S.K.; Doral, M.Y.; Borowitz, M.J.; Wood, B.L.; Chen, I.M.; Harvey, R.C.; Gastier-Foster, J.M.; Willman, C.L.; Hunger, S.P.; Mullighan, C.G.; et al. Aberrant STAT5 and PI3K/mTOR pathway signaling occurs in human CRLF2-rearranged B-precursor acute lymphoblastic leukemia. Blood 2012, 120, 833-842. [CrossRef] [PubMed]

129. Hertzberg, L.; Vendramini, E.; Ganmore, I.; Cazzaniga, G.; Schmitz, M.; Chalker, J.; Shiloh, R.; Iacobucci, I.; Shochat, C.; Zeligson, S.; et al. Down syndrome acute lymphoblastic leukemia, a highly heterogeneous disease in which aberrant expression of CRLF2 is associated with mutated JAK2: A report from the International BFM Study Group. Blood 2010, 115, 1006-1017. [CrossRef]

130. Mullighan, C.G. The molecular genetic makeup of acute lymphoblastic leukemia. Hematology 2012, 2012, 389-396. [CrossRef] [PubMed]

131. Yoda, A.; Yoda, Y.; Chiaretti, S.; Bar-Natan, M.; Mani, K.; Rodig, S.J.; West, N.; Xiao, Y.; Brown, J.R.; Mitsiades, C.; et al. Functional screening identifies CRLF2 in precursor B-cell acute lymphoblastic leukemia. Proc. Natl. Acad. Sci. USA 2010, 107, $252-257$. [CrossRef]

132. Shochat, C.; Tal, N.; Bandapalli, O.R.; Palmi, C.; Ganmore, I.; te Kronnie, G.; Cario, G.; Cazzaniga, G.; Kulozik, A.E.; Stanulla, M.; et al. Gain-of-function mutations in interleukin-7 receptor-alpha (IL7R) in childhood acute lymphoblastic leukemias. J. Exp. Med. 2011, 208, 901-908. [CrossRef]

133. Rochman, Y.; Kashyap, M.; Robinson, G.W.; Sakamoto, K.; Gomez-Rodriguez, J.; Wagner, K.-U.; Leonard, W.J. Thymic stromal lymphopoietin-mediated STAT5 phosphorylation via kinases JAK1 and JAK2 reveals a key difference from IL-7-induced signaling. Proc. Natl. Acad. Sci. USA 2010, 107, 19455-19460. [CrossRef]

134. Silva, A.; Gírio, A.; Cebola, I.; Santos, C.I.; Antunes, F.; Barata, J.T. Intracellular reactive oxygen species are essential for $\mathrm{PI} 3 \mathrm{~K} / \mathrm{Akt} / \mathrm{mTOR}-d e p e n d e n t$ IL-7-mediated viability of T-cell acute lymphoblastic leukemia cells. Leukemia 2011, 25, 960-967. [CrossRef] [PubMed]

135. Van Der Zwet, J.C.G.; Buijs-Gladdines, J.G.C.A.M.; Cordo, V.; Debets, D.; Smits, W.K.; Chen, Z.; Dylus, J.; Zaman, G.; Altelaar, M.; Oshima, K.; et al. The Central Role of MAPK-ERK Signaling in IL7-Dependent and IL7-Independent Steroid Resistance Reveals a Broad Application of MEK-Inhibitors Compared to JAK1/2-Inhibition in T-ALL. Blood 2020, 136, 20. [CrossRef]

136. Polli, M.; Dakic, A.; Light, A.; Wu, L.; Tarlinton, D.M.; Nutt, S.L. The development of Funct. B lymphocytes in conditional PU.1 knock-out mice. Blood 2005, 106, 2083-2090. [CrossRef]

137. Su, G.H.; Chen, H.-M.; Muthusamy, N.; Garrett-Sinha, L.A.; Baunoch, D.; Tenen, D.G.; Simon, M.C. Defective B cell receptormediated responses in mice lacking the Ets protein, Spi-B. EMBO J. 1997, 16, 7118-7129. [CrossRef]

138. Marty, C.; Lacout, C.; Droin, N.; Le Couédic, J.P.; Ribrag, V.; Solary, E.; Vainchenker, W.; Villeval, J.L.; Plo, I. A role for reactive oxygen species in JAK2V617F myeloproliferative neoplasm progression. Leukemia 2013, 27, 2187-2195. [CrossRef]

139. Lim, M.; Batista, C.R.; Oliveira, B.R.d.; Creighton, R.; Ferguson, J.; Clemmer, K.; Knight, D.; Iansavitchous, J.; Mahmood, D.; Avino, M.; et al. Janus Kinase Mutations in Mice Lacking PU.1 and Spi-B Drive B Cell Leukemia through Reactive Oxygen Species-Induced DNA Damage. Mol. Cell. Biol. 2020, 40, e00189-20. [CrossRef]

140. Staber, P.B.; Zhang, P.; Ye, M.; Welner, R.S.; Nombela-Arrieta, C.; Bach, C.; Kerenyi, M.; Bartholdy, B.A.; Zhang, H.; Alberich-Jordà, M.; et al. Sustained PU.1 Levels Balance Cell-Cycle Regulators to Prevent Exhaustion of Adult Hematopoietic Stem Cells. Mol. Cell 2013, 49, 934-946. [CrossRef] [PubMed]

141. Manea, A.; Manea, S.A.; Gafencu, A.V.; Raicu, M.; Simionescu, M. AP-1-dependent transcriptional regulation of NADPH oxidase in human aortic smooth muscle cells: Role of p22phox subunit. Arter. Thromb. Vasc. Biol. 2008, 28, 878-885. [CrossRef]

142. Sanchez-Martin, M.; Ferrando, A. The NOTCH1-MYC highway toward T-cell acute lymphoblastic leukemia. Blood 2017, 129, 1124-1133. [CrossRef] [PubMed]

143. Vafa, O.; Wade, M.; Kern, S.; Beeche, M.; Pandita, T.K.; Hampton, G.M.; Wahl, G.M. c-Myc Can Induce DNA Damage, Increase Reactive Oxygen Species, and Mitigate p53 Function: A Mechanism for Oncogene-Induced Genetic Instability. Mol. Cell 2002, 9, 1031-1044. [CrossRef]

144. Silva, A.; Yunes, J.A.; Cardoso, B.A.; Martins, L.R.; Jotta, P.Y.; Abecasis, M.; Nowill, A.E.; Leslie, N.R.; Cardoso, A.A.; Barata, J.T. PTEN posttranslational inactivation and hyperactivation of the PI3K/Akt pathway sustain primary T cell leukemia viability. J. Clin. Investig. 2008, 118, 3762-3774. [CrossRef] [PubMed]

145. Zhang, H.; Wang, H.; Qian, X.; Gao, S.; Xia, J.; Liu, J.; Cheng, Y.; Man, J.; Zhai, X. Genetic mutational analysis of pediatric acute lymphoblastic leukemia from a single center in China using exon sequencing. BMC Cancer 2020, 20, 211. [CrossRef] [PubMed]

146. Jerchel, I.S.; Hoogkamer, A.Q.; Ariës, I.M.; Steeghs, E.M.P.; Boer, J.M.; Besselink, N.J.M.; Boeree, A.; van de Ven, C.; de GrootKruseman, H.A.; de Haas, V.; et al. RAS pathway mutations as a predictive biomarker for treatment adaptation in pediatric B-cell precursor acute lymphoblastic leukemia. Leukemia 2018, 32, 931-940. [CrossRef]

147. Tang, C.; Li, M.-H.; Chen, Y.-L.; Sun, H.-Y.; Liu, S.-L.; Zheng, W.-W.; Zhang, M.-Y.; Li, H.; Fu, W.; Zhang, W.-J.; et al. Chemotherapyinduced niche perturbs hematopoietic reconstitution in B-cell acute lymphoblastic leukemia. J. Exp. Clin. Cancer Res. 2018, 37, 204. [CrossRef]

148. Irving, J.; Matheson, E.; Minto, L.; Blair, H.; Case, M.; Halsey, C.; Swidenbank, I.; Ponthan, F.; Kirschner-Schwabe, R.; GroeneveldKrentz, S.; et al. Ras pathway mutations are prevalent in relapsed childhood acute lymphoblastic leukemia and confer sensitivity to MEK inhibition. Blood 2014, 124, 3420-3430. [CrossRef]

149. Ksionda, O.; Melton, A.A.; Bache, J.; Tenhagen, M.; Bakker, J.; Harvey, R.; Winter, S.S.; Rubio, I.; Roose, J.P. RasGRP1 overexpression in T-ALL increases basal nucleotide exchange on Ras rendering the Ras/PI3K/Akt pathway responsive to protumorigenic cytokines. Oncogene 2016, 35, 3658-3668. [CrossRef] 
150. Mues, M.; Roose, J.P. Distinct oncogenic Ras signals characterized by profound differences in flux through the RasGDP/RasGTP cycle. Small GTPases 2017, 8, 20-25. [CrossRef]

151. Molina, J.R.; Adjei, A.A. The Ras/Raf/MAPK Pathway. J. Thorac. Oncol. 2006, 1, 7-9. [CrossRef]

152. Fernández-Medarde, A.; Santos, E. Ras in cancer and developmental diseases. Genes Cancer 2011, 2, 344-358. [CrossRef]

153. Kerstjens, M.; Driessen, E.M.C.; Willekes, M.; Pinhanços, S.S.; Schneider, P.; Pieters, R.; Stam, R.W. MEK inhibition is a promising therapeutic strategy for MLL-rearranged infant acute lymphoblastic leukemia patients carrying RAS mutations. Oncotarget 2017, 8, 14835-14846. [CrossRef]

154. Holland, M.; Castro, F.V.; Alexander, S.; Smith, D.; Liu, J.; Walker, M.; Bitton, D.; Mulryan, K.; Ashton, G.; Blaylock, M.; et al. RAC2, AEP, and ICAM1 expression are associated with CNS disease in a mouse model of pre-B childhood acute lymphoblastic leukemia. Blood 2011, 118, 638-649. [CrossRef] [PubMed]

155. Nakata, Y.; Kondoh, K.; Fukushima, S.; Hashiguchi, A.; Du, W.; Hayashi, M.; Fujimoto, J.-i.; Hata, J.-i.; Yamada, T. Mutated D4-guanine diphosphate-dissociation inhibitor is found in human leukemic cells and promotes leukemic cell invasion. Exp. Hematol. 2008, 36, 37-50. [CrossRef] [PubMed]

156. Freret, M.; Gouel, F.; Buquet, C.; Legrand, E.; Vannier, J.-P.; Vasse, M.; Dubus, I. Rac-1 GTPase controls the capacity of human leukaemic lymphoblasts to migrate on fibronectin in response to SDF-1 $\alpha$ (CXCL12). Leuk. Res. 2011, 35, 971-973. [CrossRef] [PubMed]

157. Arnaud, M.-P.; Vallée, A.; Robert, G.; Bonneau, J.; Leroy, C.; Varin-Blank, N.; Rio, A.-G.; Troadec, M.-B.; Galibert, M.-D.; Gandemer, V. CD9, a key actor in the dissemination of lymphoblastic leukemia, modulating CXCR4-mediated migration via RAC1 signaling. Blood 2015, 126, 1802-1812. [CrossRef] [PubMed]

158. Ueyama, T.; Geiszt, M.; Leto, T.L. Involvement of Rac1 in Activation of Multicomponent Nox1- and Nox3-Based NADPH Oxidases. Mol. Cell. Biol. 2006, 26, 2160-2174. [CrossRef]

159. Madajewski, B.; Boatman, M.A.; Chakrabarti, G.; Boothman, D.A.; Bey, E.A. Depleting Tumor-NQO1 Potentiates Anoikis and Inhibits Growth of NSCLC. Mol. Cancer Res. 2016, 14, 14-25. [CrossRef]

160. Ross, D.; Siegel, D. Functions of NQO1 in Cellular Protection and CoQ10 Metabolism and its Potential Role as a Redox Sensitive Molecular Switch. Front. Physiol. 2017, 8. [CrossRef]

161. Diao, J.; Bao, J.; Peng, J.; Mo, J.; Ye, Q.; He, J. Correlation between NAD(P)H: Quinone oxidoreductase 1 C609T polymorphism and increased risk of esophageal cancer: Evidence from a meta-analysis. Ther. Adv. Med Oncol. 2017, 9, 13-21. [CrossRef]

162. Smith, M.T.; Wang, Y.; Skibola, C.F.; Slater, D.J.; Nigro, L.L.; Nowell, P.C.; Lange, B.J.; Felix, C.A. Low NAD(P)H:quinone oxidoreductase activity is associated with increased risk of leukemia with MLL translocations in infants and children. Blood 2002, 100, 4590-4593. [CrossRef]

163. Freriksen, J.J.M.; Salomon, J.; Roelofs, H.M.J.; te Morsche, R.H.M.; van der Stappen, J.W.J.; Dura, P.; Witteman, B.J.M.; Lacko, M.; Peters, W.H.M. Genetic polymorphism 609C $>$ T in NAD(P)H:quinone oxidoreductase 1 enhances the risk of proximal colon cancer. J. Hum. Genet. 2014, 59, 381-386. [CrossRef] [PubMed]

164. Wiemels, J.L.; Pagnamenta, A.; Taylor, G.M.; Eden, O.B.; Alexander, F.E.; Greaves, M.F. A lack of a functional NAD(P)H:quinone oxidoreductase allele is selectively associated with pediatric leukemias that have MLL fusions. United Kingdom Childhood Cancer Study Investigators. Cancer Res. 1999, 59, 4095-4099. [PubMed]

165. Manesia, J.K.; Xu, Z.; Broekaert, D.; Boon, R.; van Vliet, A.; Eelen, G.; Vanwelden, T.; Stegen, S.; Van Gastel, N.; Pascual-Montano, A.; et al. Highly proliferative primitive fetal liver hematopoietic stem cells are fueled by oxidative metabolic pathways. Stem. Cell Res. 2015, 15, 715-721. [CrossRef] [PubMed]

166. Ma, Y.; Kong, J.; Yan, G.; Ren, X.; Jin, D.; Jin, T.; Lin, L.; Lin, Z. NQO1 overexpression is associated with poor prognosis in squamous cell carcinoma of the uterine cervix. BMC Cancer 2014, 14, 414. [CrossRef]

167. Li, Z.; Zhang, Y.; Jin, T.; Men, J.; Lin, Z.; Qi, P.; Piao, Y.; Yan, G. NQO1 protein expression predicts poor prognosis of non-small cell lung cancers. BMC Cancer 2015, 15, 207. [CrossRef]

168. Motea, E.A.; Huang, X.; Singh, N.; Kilgore, J.A.; Williams, N.S.; Xie, X.J.; Gerber, D.E.; Beg, M.S.; Bey, E.A.; Boothman, D.A. NQO1-dependent, Tumor-selective Radiosensitization of Non-small Cell Lung Cancers. Clin. Cancer Res. 2019, 25, $2601-2609$. [CrossRef]

169. Redza-Dutordoir, M.; Averill-Bates, D.A. Activation of apoptosis signalling pathways by reactive oxygen species. Biochim. Et. Biophys. Acta Mol. Cell Res. 2016, 1863, 2977-2992. [CrossRef] [PubMed]

170. Fidyt, K.; Pastorczak, A.; Goral, A.; Szczygiel, K.; Fendler, W.; Muchowicz, A.; Bartlomiejczyk, M.A.; Madzio, J.; Cyran, J.; Graczyk-Jarzynka, A.; et al. Targeting the thioredoxin system as a novel strategy against B-cell acute lymphoblastic leukemia. Mol. Oncol. 2019, 13, 1180-1195. [CrossRef]

171. Inoue, H.; Takemura, H.; Kawai, Y.; Yoshida, A.; Ueda, T.; Miyashita, T. Dexamethasone-resistant human Pre-B leukemia 697 cell line evolving elevation of intracellular glutathione level: An additional resistance mechanism. Jpn. J Cancer Res. 2002, 93, 582-590. [CrossRef]

172. Tome, M.E.; Baker, A.F.; Powis, G.; Payne, C.M.; Briehl, M.M. Catalase-overexpressing thymocytes are resistant to glucocorticoidinduced apoptosis and exhibit increased net tumor growth. Cancer Res. 2001, 61, 2766-2773.

173. Jaramillo, M.C.; Frye, J.B.; Crapo, J.D.; Briehl, M.M.; Tome, M.E. Increased manganese superoxide dismutase expression or treatment with manganese porphyrin potentiates dexamethasone-induced apoptosis in lymphoma cells. Cancer Res. 2009, 69, 5450-5457. [CrossRef] 
174. Kearns, P.R.; Pieters, R.; Rottier, M.M.A.; Pearson, A.D.J.; Hall, A.G. Raised blast glutathione levels are associated with an increased risk of relapse in childhood acute lymphocytic leukemia. Blood 2001, 97, 393-398. [CrossRef] [PubMed]

175. Xiao, S.; Xu, N.; Ding, Q.; Huang, S.; Zha, Y.; Zhu, H. LncRNA VPS9D1-AS1 promotes cell proliferation in acute lymphoblastic leukemia through modulating GPX1 expression by miR-491-5p and miR-214-3p evasion. Biosci. Rep. 2020, 40, BSR20193461. [CrossRef] [PubMed]

176. Kordes, U.; Krappmann, D.; Heissmeyer, V.; Ludwig, W.D.; Scheidereit, C. Transcription factor NF-kappaB is constitutively activated in acute lymphoblastic leukemia cells. Leukemia 2000, 14, 399-402. [CrossRef]

177. Nagel, D.; Vincendeau, M.; Eitelhuber, A.C.; Krappmann, D. Mechanisms and consequences of constitutive NF-kappaB activation in B-cell lymphoid malignancies. Oncogene 2014, 33, 5655-5665. [CrossRef] [PubMed]

178. Smale, S.T. Hierarchies of NF-kappaB target-gene regulation. Nat. Immunol. 2011, 12, 689-694. [CrossRef]

179. Wardyn, J.D.; Ponsford, A.H.; Sanderson, C.M. Dissecting molecular cross-talk between Nrf2 and NF-kappaB response pathways. Biochem. Soc. Trans. 2015, 43, 621-626. [CrossRef]

180. Oeckinghaus, A.; Ghosh, S. The NF-kappaB family of transcription factors and its regulation. Cold Spring Harb. Perspect Biol. 2009, 1, a000034. [CrossRef]

181. Anrather, J.; Racchumi, G.; Iadecola, C. NF-kappaB regulates phagocytic NADPH oxidase by inducing the expression of gp91phox. J. Biol. Chem. 2006, 281, 5657-5667. [CrossRef]

182. Madrid, L.V.; Mayo, M.W.; Reuther, J.Y.; Baldwin, A.S., Jr. Akt stimulates the transactivation potential of the RelA/p65 Subunit of NF-kappa B through utilization of the Ikappa B kinase and activation of the mitogen-activated protein kinase p38. J. Biol. Chem. 2001, 276, 18934-18940. [CrossRef]

183. Vasudevan, K.M.; Gurumurthy, S.; Rangnekar, V.M. Suppression of PTEN expression by NF-kappa B prevents apoptosis. Mol. Cell Biol. 2004, 24, 1007-1021. [CrossRef] [PubMed]

184. Gu, L.; Zhu, N.; Findley, H.W.; Zhou, M. Loss of PTEN Expression Induces NF-kB Via PI3K/Akt Pathway Involving Resistance to Chemotherapy in Acute Lymphoblastic Leukemia Cell Lines. Blood 2004. [CrossRef]

185. Katerndahl, C.D.S.; Heltemes-Harris, L.M.; Willette, M.J.L.; Henzler, C.M.; Frietze, S.; Yang, R.; Schjerven, H.; Silverstein, K.A.T.; Ramsey, L.B.; Hubbard, G.; et al. Antagonism of B cell enhancer networks by STAT5 drives leukemia and poor patient survival. Nat. Immunol. 2017, 18, 694-704. [CrossRef]

186. Hoelbl, A.; Schuster, C.; Kovacic, B.; Zhu, B.; Wickre, M.; Hoelzl, M.A.; Fajmann, S.; Grebien, F.; Warsch, W.; Stengl, G.; et al. Stat5 is indispensable for the maintenance of bcr/abl-positive leukaemia. EMBO Mol. Med. 2010, 2, 98-110. [CrossRef]

187. Schwaller, J.; Parganas, E.; Wang, D.; Cain, D.; Aster, J.C.; Williams, I.R.; Lee, C.K.; Gerthner, R.; Kitamura, T.; Frantsve, J.; et al Stat5 is essential for the myelo- and lymphoproliferative disease induced by TEL/JAK2. Mol. Cell 2000, 6, 693-704. [CrossRef]

188. Degryse, S.; de Bock, C.E.; Cox, L.; Demeyer, S.; Gielen, O.; Mentens, N.; Jacobs, K.; Geerdens, E.; Gianfelici, V.; Hulselmans, G.; et al. JAK3 mutants transform hematopoietic cells through JAK1 activation, causing T-cell acute lymphoblastic leukemia in a mouse model. Blood 2014, 124, 3092-3100. [CrossRef]

189. Wang, J.; Rao, Q.; Wang, M.; Wei, H.; Xing, H.; Liu, H.; Wang, Y.; Tang, K.; Peng, L.; Tian, Z.; et al. Overexpression of Rac1 in leukemia patients and its role in leukemia cell migration and growth. Biochem. Biophys Res. Commun. 2009, 386, 769-774. [CrossRef] [PubMed]

190. Cabrera, M.; Echeverria, E.; Lenicov, F.R.; Cardama, G.; Gonzalez, N.; Davio, C.; Fernandez, N.; Menna, P.L. Pharmacological Rac1 inhibitors with selective apoptotic activity in human acute leukemic cell lines. Oncotarget 2017, 8, 98509-98523. [CrossRef]

191. Tonelli, C.; Chio, I.I.C.; Tuveson, D.A. Transcriptional Regulation by Nrf2. Antioxid. Redox Signal. 2018, 29, 1727-1745. [CrossRef]

192. Ma, Q. Role of Nrf2 in Oxidative Stress and Toxicity. Annu. Rev. Pharmacol. Toxicol. 2013, 53, 401-426. [CrossRef]

193. Akin-Bali, D.F.; Aktas, S.H.; Unal, M.A.; Kankilic, T. Identification of novel Nrf2/Keap1 pathway mutations in pediatric acute lymphoblastic leukemia. Pediatr Hematol. Oncol. 2020, 37, 58-75. [CrossRef] [PubMed]

194. Behan, J.W.; Yun, J.P.; Proektor, M.P.; Ehsanipour, E.A.; Arutyunyan, A.; Moses, A.S.; Avramis, V.I.; Louie, S.G.; Butturini, A.; Heisterkamp, N.; et al. Adipocytes impair leukemia treatment in mice. Cancer Res. 2009, 69, 7867-7874. [CrossRef] [PubMed]

195. Sheng, X.; Tucci, J.; Parmentier, J.-H.; Ji, L.; Behan, J.W.; Heisterkamp, N.; Mittelman, S.D. Adipocytes cause leukemia cell resistance to daunorubicin via oxidative stress response. Oncotarget 2016, 7, 73147. [CrossRef] [PubMed]

196. Benjamin, C.E.; Rafal, R.A.; John, P.M.; Paraskevi, D.; Allison, B. Investigating chemoresistance to improve sensitivity of childhood T-cell acute lymphoblastic leukemia to parthenolide. Haematologica 2018, 103, 1493-1501. [CrossRef]

197. Drab, M.; Stopar, D.; Kralj-Iglič, V.; Iglič, A. Inception Mechanisms of Tunneling Nanotubes. Cells 2019, 8, 626. [CrossRef]

198. Wang, J.; Liu, X.; Qiu, Y.; Shi, Y.; Cai, J.; Wang, B.; Wei, X.; Ke, Q.; Sui, X.; Wang, Y.; et al. Cell adhesion-mediated mitochondria transfer contributes to mesenchymal stem cell-induced chemoresistance on T cell acute lymphoblastic leukemia cells. J. Hematol. Oncol. 2018, 11, 11. [CrossRef]

199. Polak, R.; de Rooij, B.; Pieters, R.; den Boer, M.L. B-cell precursor acute lymphoblastic leukemia cells use tunneling nanotubes to orchestrate their microenvironment. Blood 2015, 126, 2404-2414. [CrossRef] [PubMed]

200. Hawkins, E.D.; Duarte, D.; Akinduro, O.; Khorshed, R.A.; Passaro, D.; Nowicka, M.; Straszkowski, L.; Scott, M.K.; Rothery, S.; Ruivo, N.; et al. T-cell acute leukaemia exhibits dynamic interactions with bone marrow microenvironments. Nature 2016, 538, 518-522. [CrossRef]

201. Fahy, L.; Calvo, J.; Chabi, S.; Renou, L.; Le Maout, C.; Poglio, S.; Leblanc, T.; Petit, A.; Baruchel, A.; Ballerini, P.; et al. Hypoxia favors chemoresistance in T-ALL through an HIF1 $\alpha$-mediated mTORC1 inhibition loop. Blood Adv. 2021, 5, 513-526. [CrossRef] 
202. Takahashi, H.; Inoue, J.; Sakaguchi, K.; Takagi, M.; Mizutani, S.; Inazawa, J. Autophagy is required for cell survival under L-asparaginase-induced metabolic stress in acute lymphoblastic leukemia cells. Oncogene 2017, 36, 4267-4276. [CrossRef]

203. Wu, X.; Feng, X.; Zhao, X.; Ma, F.; Liu, N.; Guo, H.; Li, C.; Du, H.; Zhang, B. Role of Beclin-1-Mediated Autophagy in the Survival of Pediatric Leukemia Cells. Cell. Physiol. Biochem. 2016, 39, 1827-1836. [CrossRef] [PubMed]

204. Jing, B.; Jin, J.; Xiang, R.; Liu, M.; Yang, L.; Tong, Y.; Xiao, X.; Lei, H.; Liu, W.; Xu, H.; et al. Vorinostat and quinacrine have synergistic effects in T-cell acute lymphoblastic leukemia through reactive oxygen species increase and mitophagy inhibition. Cell Death Dis. 2018, 9, 589. [CrossRef] [PubMed]

205. Trachootham, D.; Alexandre, J.; Huang, P. Targeting cancer cells by ROS-mediated mechanisms: A radical therapeutic approach? Nat. Rev. Drug Discov. 2009, 8, 579-591. [CrossRef] [PubMed]

206. Phillips, D.C.; Woollard, K.J.; Griffiths, H.R. The anti-inflammatory actions of methotrexate are critically dependent upon the production of reactive oxygen species. Br. J. Pharmacol. 2003, 138, 501-511. [CrossRef]

207. Al-Aamri, H.M.; Ku, H.; Irving, H.R.; Tucci, J.; Meehan-Andrews, T.; Bradley, C. Time dependent response of daunorubicin on cytotoxicity, cell cycle and DNA repair in acute lymphoblastic leukaemia. BMC Cancer 2019, 19, 179. [CrossRef]

208. Groninger, E.; Meeuwsen-De Boer, G.J.; De Graaf, S.S.N.; Kamps, W.A.; De Bont, E.S.J.M. Vincristine induced apoptosis in acute lymphoblastic leukaemia cells: A mitochondrial controlled pathway regulated by reactive oxygen species? Int. J. Oncol. 2002, 21, 1339-1345. [CrossRef]

209. Cappetta, D.; De Angelis, A.; Sapio, L.; Prezioso, L.; Illiano, M.; Quaini, F.; Rossi, F.; Berrino, L.; Naviglio, S.; Urbanek, K. Oxidative Stress and Cellular Response to Doxorubicin: A Common Factor in the Complex Milieu of Anthracycline Cardiotoxicity. Oxid Med. Cell Longev. 2017, 2017, 1521020. [CrossRef]

210. Gidron, Y.; Russ, K.; Tissarchondou, H.; Warner, J. The relation between psychological factors and DNA-damage: A critical review. Biol. Psychol. 2006, 72, 291-304. [CrossRef]

211. Liu, W.; Zhao, Z.; Na, Y.; Meng, C.; Wang, J.; Bai, R. Dexamethasone-induced production of reactive oxygen species promotes apoptosis via endoplasmic reticulum stress and autophagy in MC3T3-E1 cells. Int. J. Mol. Med. 2018, 41, 2028-2036. [CrossRef]

212. Nguyen, L.X.T.; Troadec, E.; Kalvala, A.; Kumar, B.; Hoang, D.H.; Viola, D.; Zhang, B.; Nguyen, D.Q.; Aldoss, I.; Ghoda, L.; et al. The Bcl-2 inhibitor venetoclax inhibits Nrf2 antioxidant pathway activation induced by hypomethylating agents in AML. J. Cell. Physiol. 2019, 234, 14040-14049. [CrossRef]

213. Petruccelli, L.A.; Dupéré-Richer, D.; Pettersson, F.; Retrouvey, H.; Skoulikas, S.; Miller, W.H., Jr. Vorinostat induces reactive oxygen species and DNA damage in acute myeloid leukemia cells. PLoS ONE 2011, 6, e20987. [CrossRef]

214. Scotland, S.; Saland, E.; Skuli, N.; de Toni, F.; Boutzen, H.; Micklow, E.; Sénégas, I.; Peyraud, R.; Peyriga, L.; Théodoro, F.; et al. Mitochondrial energetic and AKT status mediate metabolic effects and apoptosis of metformin in human leukemic cells. Leukemia 2013, 27, 2129-2138. [CrossRef] [PubMed]

215. Silic-Benussi, M.; Scattolin, G.; Cavallari, I.; Minuzzo, S.; del Bianco, P.; Francescato, S.; Basso, G.; Indraccolo, S.; D’Agostino, D.M.; Ciminale, V. Selective killing of human T-ALL cells: An integrated approach targeting redox homeostasis and the OMA1/OPA1 axis. Cell Death Dis. 2018, 9, 822. [CrossRef] [PubMed]

216. Haß, C.; Belz, K.; Schoeneberger, H.; Fulda, S. Sensitization of acute lymphoblastic leukemia cells for LCL161-induced cell death by targeting redox homeostasis. Biochem. Pharmacol. 2016, 105, 14-22. [CrossRef]

217. Chou, W.-C.; Jie, C.; Kenedy, A.A.; Jones, R.J.; Trush, M.A.; Dang, C.V. Role of NADPH oxidase in arsenic-induced reactive oxygen species formation and cytotoxicity in myeloid leukemia cells. Proc. Natl. Acad. Sci. USA 2004, 101, 4578-4583. [CrossRef] [PubMed]

218. Varghese, M.V.; Manju, A.; Abhilash, M.; Paul, M.V.S.; Abhilash, S.; Nair, R.H. Oxidative stress induced by the chemotherapeutic agent arsenic trioxide. 3 Biotech 2014, 4, 425-430. [CrossRef]

219. Zhang, S.; Liu, X.; Bawa-Khalfe, T.; Lu, L.-S.; Lyu, Y.L.; Liu, L.F.; Yeh, E.T.H. Identification of the molecular basis of doxorubicininduced cardiotoxicity. Nat. Med. 2012, 18, 1639-1642. [CrossRef] [PubMed]

220. Škrtić, M.; Sriskanthadevan, S.; Jhas, B.; Gebbia, M.; Wang, X.; Wang, Z.; Hurren, R.; Jitkova, Y.; Gronda, M.; Maclean, N.; et al. Inhibition of Mitochondrial Translation as a Therapeutic Strategy for Human Acute Myeloid Leukemia. Cancer Cell 2011, 20, 674-688. [CrossRef]

221. Townsend, D.M.; Pazoles, C.J.; Tew, K.D. NOV-002, a mimetic of glutathione disulfide. Expert. Opin. Investig. Drugs 2008, 17, 1075-1083. [CrossRef]

222. Huang, P.; Feng, L.; Oldham, E.A.; Keating, M.J.; Plunkett, W. Superoxide dismutase as a target for the selective killing of cancer cells. Nature 2000, 407, 390-395. [CrossRef]

223. Doñate, F.; Juarez, J.C.; Burnett, M.E.; Manuia, M.M.; Guan, X.; Shaw, D.E.; Smith, E.L.P.; Timucin, C.; Braunstein, M.J.; Batuman, O.A.; et al. Identification of biomarkers for the antiangiogenic and antitumour activity of the superoxide dismutase 1 (SOD1) inhibitor tetrathiomolybdate (ATN-224). Br. J. Cancer 2008, 98, 776-783. [CrossRef]

224. Dvorakova, K.; Payne, C.M.; Tome, M.E.; Briehl, M.M.; McClure, T.; Dorr, R.T. Induction of oxidative stress and apoptosis in myeloma cells by the aziridine-containing agent imexon. Biochem. Pharmacol. 2000, 60, 749-758. [CrossRef]

225. Ehrenfeld, V.; Fulda, S. Thioredoxin inhibitor PX-12 induces mitochondria-mediated apoptosis in acute lymphoblastic leukemia cells. Biol. Chem. 2020, 401, 273-283. [CrossRef]

226. Kirkpatrick, D.L.; Ehrmantraut, G.; Stettner, S.; Kunkel, M.; Powis, G. Redox active disulfides: The thioredoxin system as a drug target. Oncol. Res. 1997, 9, 351-356. [PubMed] 
227. Sztiller-Sikorska, M.; Czyz, M. Parthenolide as Cooperating Agent for Anti-Cancer Treatment of Various Malignancies. Pharmaceuticals 2020, 13, 194. [CrossRef] [PubMed]

228. Griffith, O.W.; Meister, A. Potent and specific inhibition of glutathione synthesis by buthionine sulfoximine (S-n-butyl homocysteine sulfoximine). J. Biol. Chem. 1979, 254, 7558-7560. [CrossRef]

229. Mendivil-Perez, M.; Velez-Pardo, C.; Jimenez-Del-Rio, M. TPEN Induces Apoptosis Independently of Zinc Chelator Activity in a Model of Acute Lymphoblastic Leukemia and Ex Vivo Acute Leukemia Cells through Oxidative Stress and Mitochondria Caspase-3- and AIF-Dependent Pathways. Oxid Med. Cell Longev. 2012, 2012, 313275. [CrossRef]

230. Hashemi, M.; Ghavami, S.; Eshraghi, M.; Booy, E.P.; Los, M. Cytotoxic effects of intra and extracellular zinc chelation on human breast cancer cells. Eur. J. Pharmacol. 2007, 557, 9-19. [CrossRef]

231. Afrin, F.; Chi, M.; Eamens, A.L.; Duchatel, R.J.; Douglas, A.M.; Schneider, J.; Gedye, C.; Woldu, A.S.; Dun, M.D. Can Hemp Help? Low-THC Cannabis and Non-THC Cannabinoids for the Treatment of Cancer. Cancers 2020, 12, 1033. [CrossRef]

232. Kuttikrishnan, S.; Siveen, K.S.; Prabhu, K.S.; Khan, A.Q.; Ahmed, E.I.; Akhtar, S.; Ali, T.A.; Merhi, M.; Dermime, S.; Steinhoff, M.; et al. Curcumin Induces Apoptotic Cell Death via Inhibition of PI3-Kinase/AKT Pathway in B-Precursor Acute Lymphoblastic Leukemia. Front. Oncol. 2019, 9. [CrossRef]

233. Yamada, T.; Egashira, N.; Imuta, M.; Yano, T.; Yamauchi, Y.; Watanabe, H.; Oishi, R. Role of oxidative stress in vinorelbine-induced vascular endothelial cell injury. Free. Radic. Biol. Med. 2010, 48, 120-127. [CrossRef] [PubMed]

234. Gibellini, L.; Pinti, M.; Nasi, M.; De Biasi, S.; Roat, E.; Bertoncelli, L.; Cossarizza, A. Interfering with ROS Metabolism in Cancer Cells: The Potential Role of Quercetin. Cancers 2010, 2, 1288-1311. [CrossRef] [PubMed]

235. Sun, Y.; Zheng, Y.; Wang, C.; Liu, Y. Glutathione depletion induces ferroptosis, autophagy, and premature cell senescence in retinal pigment epithelial cells. Cell Death Dis. 2018, 9, 753. [CrossRef]

236. Marzano, C.; Gandin, V.; Folda, A.; Scutari, G.; Bindoli, A.; Rigobello, M.P. Inhibition of thioredoxin reductase by auranofin induces apoptosis in cisplatin-resistant human ovarian cancer cells. Free. Radic. Biol. Med. 2007, 42, 872-881. [CrossRef]

237. Liu, C.-X.; Yin, Q.-Q.; Zhou, H.-C.; Wu, Y.-L.; Pu, J.-X.; Xia, L.; Liu, W.; Huang, X.; Jiang, T.; Wu, M.-X.; et al. Adenanthin targets peroxiredoxin I and II to induce differentiation of leukemic cells. Nat. Chem. Biol. 2012, 8, 486-493. [CrossRef]

238. Dächert, J.; Schoeneberger, H.; Rohde, K.; Fulda, S. RSL3 and Erastin differentially regulate redox signaling to promote Smac mimetic-induced cell death. Oncotarget 2016, 7, 63779-63792. [CrossRef]

239. Aghvami, M.; Ebrahimi, F.; Zarei, M.H.; Salimi, A.; Pourahmad Jaktaji, R.; Pourahmad, J. Matrine Induction of ROS Mediated Apoptosis in Human ALL B-lymphocytes Via Mitochondrial Targeting. Asian Pac. J. Cancer Prev. 2018, 19, 555-560. [CrossRef] [PubMed]

240. Orsolic, N.; Golemovic, M.; Quintás-Cardama, A.; Scappini, B.; Manshouri, T.; Chandra, J.; Basic, I.; Giles, F.; Kantarjian, H.; Verstovsek, S. Adaphostin has significant and selective activity against chronic and acute myeloid leukemia cells. Cancer Sci. 2006, 97, 952-960. [CrossRef] [PubMed]

241. Haffo, L.; Lu, J.; Bykov, V.J.N.; Martin, S.S.; Ren, X.; Coppo, L.; Wiman, K.G.; Holmgren, A. Inhibition of the glutaredoxin and thioredoxin systems and ribonucleotide reductase by mutant p53-targeting compound APR-246. Sci. Rep. 2018, 8, 12671. [CrossRef]

242. Kuttikrishnan, S.; Siveen, K.S.; Prabhu, K.S.; Khan, A.Q.; Akhtar, S.; Mateo, J.M.; Merhi, M.; Taha, R.; Omri, H.E.; Mraiche, F.; et al. Sanguinarine suppresses growth and induces apoptosis in childhood acute lymphoblastic leukemia. Leuk. Lymphoma 2019, 60, 782-794. [CrossRef]

243. Xu, X.; Huang, L.; Zhang, Z.; Tong, J.; Mi, J.; Wu, Y.; Zhang, C.; Yan, H. Targeting non-oncogene ROS pathway by alantolactone in B cell acute lymphoblastic leukemia cells. Life Sci. 2019, 227, 153-165. [CrossRef]

244. Gregory, M.A.; Nemkov, T.; Park, H.J.; Zaberezhnyy, V.; Gehrke, S.; Adane, B.; Jordan, C.T.; Hansen, K.C.; D’Alessandro, A.; DeGregori, J. Targeting Glutamine Metabolism and Redox State for Leukemia Therapy. Clin. Cancer Res. J. Am. Assoc. Cancer Res. 2019, 25, 4079-4090. [CrossRef] [PubMed]

245. Najafi Dorcheh, S.; Rahgozar, S.; Talei, D. 6-Shogaol induces apoptosis in acute lymphoblastic leukaemia cells by targeting p53 signalling pathway and generation of reactive oxygen species. J. Cell. Mol. Med. 2021, 25, 6148-6160. [CrossRef] [PubMed]

246. Ma, R.-H.; Ni, Z.-J.; Zhang, F.; Zhang, Y.-Y.; Liu, M.-M.; Thakur, K.; Zhang, J.-G.; Wang, S.; Wei, Z.-J. 6-Shogaol mediated ROS production and apoptosis via endoplasmic reticulum and mitochondrial pathways in human endometrial carcinoma Ishikawa cells. J. Funct. Foods 2020, 74, 104178. [CrossRef]

247. Zorov, D.B.; Juhaszova, M.; Sollott, S.J. Mitochondrial reactive oxygen species (ROS) and ROS-induced ROS release. Physiol. Rev. 2014, 94, 909-950. [CrossRef]

248. Dong, L.; Gopalan, V.; Holland, O.; Neuzil, J. Mitocans Revisited: Mitochondrial Targeting as Efficient Anti-Cancer Therapy. Int. J. Mol. Sci. 2020, 21, 7941. [CrossRef]

249. Fu, X.; Liu, W.; Huang, Q.; Wang, Y.; Li, H.; Xiong, Y. Targeting mitochondrial respiration selectively sensitizes pediatric acute lymphoblastic leukemia cell lines and patient samples to standard chemotherapy. Am. J. Cancer Res. 2017, 7, $2395-2405$.

250. Ishizawa, J.; Zarabi, S.F.; Davis, R.E.; Halgas, O.; Nii, T.; Jitkova, Y.; Zhao, R.; St-Germain, J.; Heese, L.E.; Egan, G.; et al. Mitochondrial ClpP-Mediated Proteolysis Induces Selective Cancer Cell Lethality. Cancer Cell 2019, 35, 721-737. [CrossRef]

251. Dong, L.F.; Low, P.; Dyason, J.C.; Wang, X.F.; Prochazka, L.; Witting, P.K.; Freeman, R.; Swettenham, E.; Valis, K.; Liu, J.; et al. Alpha-tocopheryl succinate induces apoptosis by targeting ubiquinone-binding sites in mitochondrial respiratory complex II. Oncogene 2008, 27, 4324-4335. [CrossRef] 
252. Ruiz-Moreno, C.; Jimenez-Del-Rio, M.; Sierra-Garcia, L.; Lopez-Osorio, B.; Velez-Pardo, C. Vitamin E synthetic derivate-TPGSselectively induces apoptosis in jurkat $\mathrm{t}$ cells via oxidative stress signaling pathways: Implications for acute lymphoblastic leukemia. Apoptosis 2016, 21, 1019-1032. [CrossRef] [PubMed]

253. Ivanova, D.; Zhelev, Z.; Semkova, S.; Aoki, I.; Bakalova, R. Resveratrol Modulates the Redox-status and Cytotoxicity of Anticancer Drugs by Sensitizing Leukemic Lymphocytes and Protecting Normal Lymphocytes. Anticancer. Res. 2019, 39, $3745-3755$. [CrossRef] [PubMed]

254. Dörrie, J.; Gerauer, H.; Wachter, Y.; Zunino, S.J. Resveratrol Induces Extensive Apoptosis by Depolarizing Mitochondrial Membranes and Activating Caspase-9 in Acute Lymphoblastic Leukemia Cells. Cancer Res. 2001, 61, 4731-4739. [PubMed]

255. Larasati, Y.A.; Yoneda-Kato, N.; Nakamae, I.; Yokoyama, T.; Meiyanto, E.; Kato, J.-y. Curcumin targets multiple enzymes involved in the ROS metabolic pathway to suppress tumor cell growth. Sci. Rep. 2018, 8, 2039. [CrossRef] [PubMed]

256. Zhang, D.; Luo, Z.; Jin, Y.; Chen, Y.; Yang, T.; Yang, Q.; Wu, B.; Shang, Y.; Liu, X.; Wei, Y.; et al. Azelaic Acid Exerts Antileukemia Effects against Acute Myeloid Leukemia by Regulating the Prdxs/ROS Signaling Pathway. Oxid Med. Cell Longev. 2020, 2020, 1295984. [CrossRef]

257. Kim, Y.W.; Byzova, T.V. Oxidative stress in angiogenesis and vascular disease. Blood 2014, 123, 625-631. [CrossRef] [PubMed]

258. Zeng, C.; Wu, Q.; Wang, J.; Yao, B.; Ma, L.; Yang, Z.; Li, J.; Liu, B. NOX4 supports glycolysis and promotes glutamine metabolism in non-small cell lung cancer cells. Free. Radic. Biol. Med. 2016, 101, 236-248. [CrossRef] [PubMed]

259. Dabral, S.; Muecke, C.; Valasarajan, C.; Schmoranzer, M.; Wietelmann, A.; Semenza, G.L.; Meister, M.; Muley, T.; Seeger-Nukpezah, T.; Samakovlis, C.; et al. A RASSF1A-HIF1 $\alpha$ loop drives Warburg effect in cancer and pulmonary hypertension. Nat. Commun. 2019, 10, 2130. [CrossRef] [PubMed]

260. Hole, P.S.; Zabkiewicz, J.; Munje, C.; Newton, Z.; Pearn, L.; White, P.; Marquez, N.; Hills, R.K.; Burnett, A.K.; Tonks, A.; et al. Overproduction of NOX-derived ROS in AML promotes proliferation and is associated with defective oxidative stress signaling. Blood 2013, 122, 3322-3330. [CrossRef] [PubMed]

261. Echizen, K.; Horiuchi, K.; Aoki, Y.; Yamada, Y.; Minamoto, T.; Oshima, H.; Oshima, M. NF-kB-induced NOX1 activation promotes gastric tumorigenesis through the expansion of SOX2-positive epithelial cells. Oncogene 2019, 38, 4250-4263. [CrossRef]

262. Shanmugasundaram, K.; Nayak, B.K.; Friedrichs, W.E.; Kaushik, D.; Rodriguez, R.; Block, K. NOX4 functions as a mitochondrial energetic sensor coupling cancer metabolic reprogramming to drug resistance. Nat. Commun. 2017, 8, 997. [CrossRef]

263. Sallmyr, A.; Fan, J.; Datta, K.; Kim, K.T.; Grosu, D.; Shapiro, P.; Small, D.; Rassool, F. Internal tandem duplication of FLT3 (FLT3/ITD) induces increased ROS production, DNA damage, and misrepair: Implications for poor prognosis in AML. Blood 2008, 111, 3173-3182. [CrossRef]

264. Zhang, J.; Li, H.; Wu, Q.; Chen, Y.; Deng, Y.; Yang, Z.; Zhang, L.; Liu, B. Tumoral NOX4 recruits M2 tumor-associated macrophages via ROS/PI3K signaling-dependent various cytokine production to promote NSCLC growth. Redox Biol. 2019, $22,101116$. [CrossRef]

265. Ford, K.; Hanley, C.J.; Mellone, M.; Szyndralewiez, C.; Heitz, F.; Wiesel, P.; Wood, O.; Machado, M.; Lopez, M.-A.; Ganesan, A.-P.; et al. NOX4 Inhibition Potentiates Immunotherapy by Overcoming Cancer-Associated Fibroblast-Mediated CD8 T-cell Exclusion from Tumors. Cancer Res. 2020, 80, 1846-1860. [CrossRef]

266. Hanley, C.J.; Mellone, M.; Ford, K.; Thirdborough, S.M.; Mellows, T.; Frampton, S.J.; Smith, D.M.; Harden, E.; Szyndralewiez, C.; Bullock, M.; et al. Targeting the Myofibroblastic Cancer-Associated Fibroblast Phenotype Through Inhibition of NOX4. JNCI: J. Natl. Cancer Inst. 2017, 110, 109-120. [CrossRef] [PubMed]

267. O'Leary, D.P.; Bhatt, L.; Woolley, J.F.; Gough, D.R.; Wang, J.H.; Cotter, T.G.; Redmond, H.P. TLR-4 Signalling Accelerates Colon Cancer Cell Adhesion via NF-kB Mediated Transcriptional Up-Regulation of Nox-1. PLoS ONE 2012, 7, e44176. [CrossRef]

268. Raad, H.; Serrano-Sanchez, M.; Harfouche, G.; Mahfouf, W.; Bortolotto, D.; Bergeron, V.; Kasraian, Z.; Dousset, L.; Hosseini, M.; Taieb, A.; et al. NADPH Oxidase-1 Plays a Key Role in Keratinocyte Responses to UV Radiation and UVB-Induced Skin Carcinogenesis. J. Investig. Dermatol. 2017, 137, 1311-1321. [CrossRef]

269. Liang, S.; Ma, H.-Y.; Zhong, Z.; Dhar, D.; Liu, X.; Xu, J.; Koyama, Y.; Nishio, T.; Karin, D.; Karin, G.; et al. NADPH Oxidase 1 in Liver Macrophages Promotes Inflammation and Tumor Development in Mice. Gastroenterology 2019, 156, 1156-1172.e1156. [CrossRef]

270. Buck, T.; Hack, C.T.; Berg, D.; Berg, U.; Kunz, L.; Mayerhofer, A. The NADPH oxidase 4 is a major source of hydrogen peroxide in human granulosa-lutein and granulosa tumor cells. Sci. Rep. 2019, 9, 3585. [CrossRef]

271. Marlein, C.R.; Zaitseva, L.; Piddock, R.E.; Robinson, S.D.; Edwards, D.R.; Shafat, M.S.; Zhou, Z.; Lawes, M.; Bowles, K.M.; Rushworth, S.A. NADPH oxidase-2 derived superoxide drives mitochondrial transfer from bone marrow stromal cells to leukemic blasts. Blood 2017, 130, 1649-1660. [CrossRef] [PubMed]

272. Elbatreek, M.H.; Mucke, H.; Schmidt, H. NOX Inhibitors: From Bench to Naxibs to Bedside. Handb. Exp. Pharm. 2021, 264, 145-168. [CrossRef]

273. Reis, J.; Massari, M.; Marchese, S.; Ceccon, M.; Aalbers, F.S.; Corana, F.; Valente, S.; Mai, A.; Magnani, F.; Mattevi, A. A closer look into NADPH oxidase inhibitors: Validation and insight into their mechanism of action. Redox Biol. 2020, 32, 101466. [CrossRef] [PubMed]

274. Lee, E.; Chung, C.H.; Huh, J.H.; Lee, S.H. 2033-P: APX-115, a Pan-NADPH Oxidase (NOX) Inhibitor, Ameliorates Diabetic Nephropathy in NOX5 Transgenic Mice. Diabetes 2019, 68, 2033-P. [CrossRef] 
275. Urner, S.; Ho, F.; Jha, J.C.; Ziegler, D.; Jandeleit-Dahm, K. NADPH Oxidase Inhibition: Preclinical and Clinical Studies in Diabetic Complications. Antioxid. Redox Signal. 2020, 33, 415-434. [CrossRef] [PubMed]

276. Cao, W.L.; Xiang, X.H.; Chen, K.; Xu, W.; Xia, S.H. Potential role of NADPH oxidase in pathogenesis of pancreatitis. World J. Gastrointest Pathophysiol. 2014, 5, 169-177. [CrossRef]

277. Hirano, K.; Chen, W.S.; Chueng, A.L.; Dunne, A.A.; Seredenina, T.; Filippova, A.; Ramachandran, S.; Bridges, A.; Chaudry, L.; Pettman, G.; et al. Discovery of GSK2795039, a Novel Small Molecule NADPH Oxidase 2 Inhibitor. Antioxid. Redox Signal. 2015, 23, 358-374. [CrossRef] [PubMed]

278. Cha, J.J.; Min, H.S.; Kim, K.T.; Kim, J.E.; Ghee, J.Y.; Kim, H.W.; Lee, J.E.; Han, J.Y.; Lee, G.; Ha, H.J.; et al. APX-115, a first-in-class pan-NADPH oxidase (Nox) inhibitor, protects $\mathrm{db} / \mathrm{db}$ mice from renal injury. Lab. Investig. 2017, 97, 419-431. [CrossRef] [PubMed]

279. Green, D.E.; Murphy, T.C.; Kang, B.-Y.; Kleinhenz, J.M.; Szyndralewiez, C.; Page, P.; Sutliff, R.L.; Hart, C.M. The Nox4 Inhibitor GKT137831 Attenuates Hypoxia-Induced Pulmonary Vascular Cell Proliferation. Am. J. Respir. Cell Mol. Biol. 2012, 47, 718-726. [CrossRef]

280. Gorin, Y.; Cavaglieri, R.C.; Khazim, K.; Lee, D.-Y.; Bruno, F.; Thakur, S.; Fanti, P.; Szyndralewiez, C.; Barnes, J.L.; Block, K.; et al. Targeting NADPH oxidase with a novel dual Nox1/Nox4 inhibitor attenuates renal pathology in type 1 diabetes. Am. J. Physiol. Ren. Physiol. 2015, 308, F1276-F1287. [CrossRef]

281. Ostrowski, R.P.; Tang, J.; Zhang, J.H. Hyperbaric Oxygen Suppresses NADPH Oxidase in a Rat Subarachnoid Hemorrhage Model. Stroke 2006, 37, 1314-1318. [CrossRef]

282. Liu, W.; Sood, R.; Chen, Q.; Sakoglu, U.; Hendren, J.; Çetin, Ö.; Miyake, M.; Liu, K.J. Normobaric hyperoxia inhibits NADPH oxidase-mediated matrix metalloproteinase-9 induction in cerebral microvessels in experimental stroke. J. Neurochem. 2008, 107, 1196-1205. [CrossRef]

283. Kochanski, R.; Peng, C.; Higashida, T.; Geng, X.; Hüttemann, M.; Guthikonda, M.; Ding, Y. Neuroprotection conferred by post-ischemia ethanol therapy in experimental stroke: An inhibitory effect on hyperglycolysis and NADPH oxidase activation. $J$. Neurochem. 2013, 126, 113-121. [CrossRef] [PubMed]

284. Dang, P.M.-C.; Fontayne, A.; Hakim, J.; El Benna, J.; Périanin, A. Protein Kinase C $\zeta$ Phosphorylates a Subset of Selective Sites of the NADPH Oxidase Component $\mathrm{p} 47_{\mathrm{phox}}$ and Participates in Formyl Peptide-Mediated Neutrophil Respiratory Burst. J. Immunol. 2001, 166, 1206-1213. [CrossRef] [PubMed]

285. Doroshow, J.H.; Gaur, S.; Markel, S.; Lu, J.; van Balgooy, J.; Synold, T.W.; Xi, B.; Wu, X.; Juhasz, A. Effects of iodonium-class flavin dehydrogenase inhibitors on growth, reactive oxygen production, cell cycle progression, NADPH oxidase 1 levels, and gene expression in human colon cancer cells and xenografts. Free. Radic. Biol. Med. 2013, 57, 162-175. [CrossRef] [PubMed]

286. Stolk, J.; Hiltermann, T.J.; Dijkman, J.H.; Verhoeven, A.J. Characteristics of the inhibition of NADPH oxidase activation in neutrophils by apocynin, a methoxy-substituted catechol. Am. J. Respir. Cell Mol. Biol. 1994, 11, 95-102. [CrossRef]

287. Liu, Z.; Tuo, Y.-H.; Chen, J.-W.; Wang, Q.-Y.; Li, S.; Li, M.-C.; Dai, G.; Wang, J.-S.; Zhang, Y.-L.; Feng, L.; et al. NADPH oxidase inhibitor regulates microRNAs with improved outcome after mechanical reperfusion. J. NeuroInterventional Surg. 2017, 9, 702-706. [CrossRef]

288. Jaquet, V.; Marcoux, J.; Forest, E.; Leidal, K.G.; McCormick, S.; Westermaier, Y.; Perozzo, R.; Plastre, O.; Fioraso-Cartier, L.; Diebold, B.; et al. NADPH oxidase (NOX) isoforms are inhibited by celastrol with a dual mode of action. Br. J. Pharmacol. 2011, 164, 507-520. [CrossRef]

289. Cifuentes-Pagano, E.; Csanyi, G.; Pagano, P.J. NADPH oxidase inhibitors: A decade of discovery from Nox2ds to HTS. Cell Mol. Life Sci. 2012, 69, 2315-2325. [CrossRef]

290. Smith, S.M.E.; Min, J.; Ganesh, T.; Diebold, B.; Kawahara, T.; Zhu, Y.; McCoy, J.; Sun, A.; Snyder, J.P.; Fu, H.; et al. Ebselen and Congeners Inhibit NADPH Oxidase 2-Dependent Superoxide Generation by Interrupting the Binding of Regulatory Subunits. Chem. Biol. 2012, 19, 752-763. [CrossRef]

291. Aoyama, T.; Paik, Y.-H.; Watanabe, S.; Laleu, B.; Gaggini, F.; Fioraso-Cartier, L.; Molango, S.; Heitz, F.; Merlot, C.; Szyndralewiez, C.; et al. Nicotinamide adenine dinucleotide phosphate oxidase in experimental liver fibrosis: GKT137831 as a novel potential therapeutic agent. Hepatology 2012, 56, 2316-2327. [CrossRef]

292. Chen, B.; Zhao, J.; Zhang, S.; Wu, W.; Qi, R. Aspirin Inhibits the Production of Reactive Oxygen Species by Downregulating Nox4 and Inducible Nitric Oxide Synthase in Human Endothelial Cells Exposed to Oxidized Low-density Lipoprotein. J. Cardiovasc. Pharmacol. 2012, 59, 405-412. [CrossRef] 